Portland State University

PDXScholar

5-6-1975

\title{
A Comparative Study of the Reponses by Varying Socioeconomic Groups on General Knowledge and Categorization Tasks
}

Margo I. Keller

Portland State University

Follow this and additional works at: https://pdxscholar.library.pdx.edu/open_access_etds

Part of the Educational Assessment, Evaluation, and Research Commons, Educational Psychology Commons, and the Education Economics Commons

Let us know how access to this document benefits you.

\section{Recommended Citation}

Keller, Margo I., "A Comparative Study of the Reponses by Varying Socioeconomic Groups on General Knowledge and Categorization Tasks" (1975). Dissertations and Theses. Paper 2244.

https://doi.org/10.15760/etd.2241

This Thesis is brought to you for free and open access. It has been accepted for inclusion in Dissertations and Theses by an authorized administrator of PDXScholar. Please contact us if we can make this document more accessible: pdxscholar@pdx.edu. 
AN ABSTRACT OF THE THESIS OF Margo I. Keller for the Master of Seienre in Speech Communication: Emphasis in Speech Pathology/Audiology, presented May 6, 1975.

Title: A Comparative Study of the Responses by Varying Socioeconomic Groups on General Knowledge and Categorization Tasks.

APPROVED BY MEMBERS OF THE THESIS COMMITTEE:

Soan McMahon, Chairman

Mary Gordon

Fay Sorginson

/7

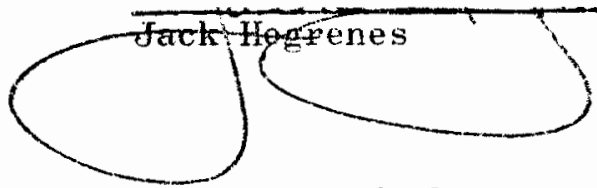

This study sought to determine if there are any "cultural" or

economic level patterns of behavior in responding to tasks involving categorizing pictures and recalling general knowledge. The Daberon School lieadiness Device (1972), which contains subtests for general knowledge and categorization, was used to assess four groups of children: 1) lower-SES white, 2) lower-SES black, 3) middle-SES white, and 
4) middle-SES black. This study involved thirty black and thirty white children between the ages of five years and five years, eleven months. All subjects were screened to determine race, age, auditory acuity, speech intelligibility, subject cooperation, and socioeconomic status (SES). Testing for intelligence was performed at the beginning of the testing situation.

The study was designed to determine whether one ethnic or SES level group would correctly identify significantly more general knowledge and/or categorization items on the Daberon than other ethnic and SES groups. Further, the study sought to determine if there were any significant patterns evident between ethnic and SES groups in the way they responded to general knowledge tasks. Finally, the study was conducted to determine whether there was any statistically significant relationship between scores earned by all subjects on the Slosson Intelligence Test for Children and Adults (1963) and those scores earued by all subjects on the Daberon School Readiness Device (1972).

Results of the study indicate white subjects answered significantly more general knowledge tasks than black subjects. Significant differences also were noted in patierns of responses to general knowledge tasks. White subjects responded significantly more often with general concept-type responses as opposed to specific concept responses than black subjects. No statistical significance was noted between ethnic and SES groups in responding to categorization tasks. Finally, statistical significance was present between Slosson Intellirence Test scores and those scores earned on the general knowledge and categorization subtests of the Daberon School Readiness Device. These results indicate a posi- 
tive correlation between a child's ability to function in the area of general knowledge and categorization and his general intelligence.

It is postulated that factors which might influence Daberon general knowledge subtest scores and patterns of responses are: 1) the influence of linguistic systems within the child's home environment and 2) the subject's ability to respond by utilizing abstract thinking rather than by relying heavily on implicit meaning. 
A COMPARATIVE STUDY OF THE RESPONSES BY VARYING SOCIOECONOMIC GROUPS ON GENERAL KNOWLEIDGE AND CATEGORIZATION TASKS

\author{
by
}

MARGO I. KELLER

A thesis submitted in partial fulfillment of the requirements for the degree of

MASTER OF SCIENCE IN SPEECH COMMUNICATION:

with an emphasis in

SPEECH PATHOLOGI/AUDIOLOGY

Portland State University

1975 
TO THE OFFICE OF GRADUATE STUDIES AND RESEARCH:

The members of the Committee approve the thesis of Margo I. Keller presented May 6, 1975.

Joan McMahon, Chairman

Mary Gordon

Fay Sorgtison

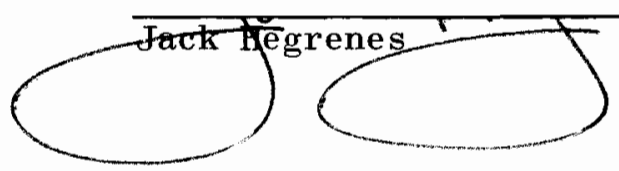

APPROVED :

Robqrt W. Vogelsang, Hegd, Departmght of Speech Communication

David T. Clark, Dean of Graduate Studies and Research

May 6, 1975 


\section{ACKNOWLEDGMENTS}

I wish to express my sincere gratitude and appreciation to Joan McMahon, my friend, committee chairman, and graduate advisor, for her eternal support and help so generously given. Without her gentle prodding and long hours in assisting me, this research would not have been completed. I extend my special thanks and appreciation to my committee members Mary Gordon and Dr. Fay Sorenson for their help and support. My thanks and appreciation to my committee member Dr. Jack Hegrenes for his devoted help and patience in completing the research statistics and to Tom Owens, who came to my rescue more than once with his statistical knowledge and assistance--without their help and knowledge the research statistics would not have been possible.

To Teddy Lyons, Virginia Danzer, and Mary Francis Gerber, the three developers of the Daberon School Readiness Device, my special thanks for their generous time, effort and support. My thanks also to the principals, teachers and children involved in this study for their patience and assistance in this research work.

To my wonderful husband, Michael, and all my family--my father, Armond LaFond, Norman and Jane Johnson, and George and Ella Keller--my love and deep appreciation for their tremendous support, encouragement, and patience during my graduate study. Without their love and understanding this research would have been impossible.

I dedicate this thesis to my mother, Marjorie LaFond, who always had unbelievable faith in me! 
TABLE OF CONTENTS

PAGE

ACKNOWLFDGMFNTS. . . . . . . . . . . . . . . . . iji

LIST OF TABLLS . . . . . . . . . . . . . . . . . . vi v v v

LIST OF FTGUTS. . . . . . . . . . . . . . . . . . v viii

\section{CEAPTER}

I INTRODUCTION AND STATEMENT OF THE PROBLEY. . . . . . 1

II REVIEW OF THE LTTERATURE . . . . . . . . . . . 5

Lánguage and Cognition Development . . . . . . 5

Culturaỉ Differences in Language ond Sognition

Development. . . . . . . . . . . . 3

Correlation Between SES and Language Develomint. 15

Educational Tingiscations . . . . . . . . 20

III METHODS AND IROCFUURES . . . . . . . . . . . . . 25

Subjects. . . . . . . . . . . . . . . 25

Variables. . . . . . . . . . . . . . 25

Are

Ricice

Auditory Acuity

Speech Intelligibility

Suoject Cooperation

Socioecuncmic status

Inte 11 i grenge

Instrumeritition. . . . . . . . . . . . .

Instruments

iest Arininistration

Data Analysis. . . . . . . . . . . . . 
IV RESULTS AND DTSCUSSTON . . . . . . . . . . .

Resuits. . . . . . . . . . . . . .

General Knowledge

Categorization

Intelligence Correlation

Discussion . . . . . . . . . . . . . 47

v SLMLRY AND IMLICATIONS . . . . . . . . . 59

Sumary. . . . . . . . . . . . 59

Inplications for Clinic and Future Research. . . 60

C1inic

Hesearch

SELECTED BIBLIOGMLPHY. . . . . . . . . . . . . . . .

APPENDICES

A GESELL DEVELPMENTAL PATTERNS FOR FTMLIEMR-.LD

CHIDDREN . . . . . . . . . . . . . .

B DABEIDON GERERAL KNOHLEDG ANT CATEGORIZATIUN QUESTIONS. . . . . . . . . . . . . 71

C FXAMLES OF GENERAL AND SPECTTIC RESTONSES TO GWTRA KNOVLEDGE ITEMS $16,18,22$, AND $23 . .$. 


\section{LIST OF TABLES}

TABIE

PAGE

I Analysis of Variarce Results for General Know]edge and Categorization Total scores $(N=60)$. . . .

II Mean Age of Each Socioecononic Group Included in Stady.

III General Knowledge Scores Achieved by the Four Major Sociocconomic Groups Including Mean and S.D. . . . 34

IV Values of $\underline{t}$ Relative to General Knovledge Scores for Comparison with Race and Socioeconomic Status...

$\mathrm{V}$ Number of Subjects in A11 SES Groups Responding Correctly to General Knowledge and Categorization

Tasks on the Daberon. .............

VI General Kiowledge Questions Showing a bifference Between Racial and SES Groups Tested. . . . . . 38

VII Total Number of Correct General ve. Specific Concept Fesponses on General Knowledge Tasks by All

Racial and SES Groups . . . . . . . . . .

IIII Resalts of Total Population on All General Knowledge Questions Which hequire General or Specific Concept Responses . . . . . . . . . . . .

IX Question 16, "What, Does a Dentist Do?" General and Specific Concept Expression . . . . . . . .

$\mathrm{X}$ Question 18, "What Do Iou Do When You Are Hungry?" General and Specific Concept Expression. . . . .

XI Guetion 22, "What Is a Key Fors" General and Specifie Concept Expression . . . . . . . . .

XIJ Question 23, "mat is an Umbrella For?" General and Specific Concept Expression . . . . . . .

XIII Means and Standard Deviations For All Racial and Socioeconomic Groups on Categorization lasks. . . 
XIV Values of t Reiative to Categorization Scores:

for the Conporison of Hace and Socioeconomic 


\section{IIST OF FIGURES}

PICURE

PAGE

1 General Inowledge Iteins Showing a Difference

Between Ethnic Groups Correctly Respouding

to These Items. . . . . . . . . .....

2 General knowledge Items Showing a Statistical

Signilicance Between Ethnic Groups on

General and Specific Types of hesponses . . .

3 All Categorization Items on the Daberor School

Readiness Dovice. . . . . . . . . . • 
CHAPTER I

INTRODUC, TON

language oncept derelopment is one of the primazy considerations in om edicational system today. Betwecn inianey and aye five or six years, tremendous language dovelopment occurs (bibex: 1967). By the end of the child's kindergartan year, his yethoo of learnge about his workt has reached an advanced and complicated stage and ho will have extexded his intexests, and knowledge into practicalty all reains of human experience. It is erucial, therefore, that every child should be given an equal opportunity to develop these language concept skills. The literature zugrests that a child's ability bo function in the areas of generai knowledge and categorization corelates positivaly with general inteldigence. It is felt that general intelligence is reflected in the range of an indivitual's information and his ability to diseriminate vithin and betweer categories. Paxt of a child's mastery of language depends upon his being lelped to establish a wioh and skillfui use go languge which will enablo him to deal no afficiently within this seciety's verba? communication system.

Mary aiagnostic tests are available to assess language abilities in children; the results of these tests are generally used to desirna weatiment program for the individnal. Welcher (1970) believed that no series of rests, hoverer skilliully administerea, revenis an irmate intellectual endowent, bat rather measures whatever inteliectunl copacity 
there nay be in conjumetion with all the inflaerces to which a child has been subjected. Ii appeared to Welcher that disadvantaged chiluren are less often exposed to the kinds of infornation fond on intelligence tests and are thus less able to cope with then. Therefore, test results may not be a valid basis unon which to plan treatment strategies since not all testing instrunents may be appromiate for ench econovic Jevel or cultural group being evaluated. Many of the tests are based on a bread, all-encompassing norm level, and it would appear necessary to establish nomative level of ability on diagostic instruments after taking into account the variables of economic level or cultural background.

As Bernstein (1970) stated, ofter in an educational setting the language of black children is misinterpreted as "simply poor language." Hence, a definite need exists icr eiucators to be nore aware tiat black language does contain a vast potential of meaning. He further stated that if the contexts of learning (i.e., the reading books and teaching materials) are rot presented in contexts which act as "iriggers' for the child's inagery-n"if these materials are not triggers on his curicsity and explorations in his family and commity," the child will not be comfortable in the educational vorld. Bernsiein consuded that it is considered an accepted educational principle that we should work with what the child can offer and not regard him as totally uneducated. There needs to be, as liortion (1970) commented, an attempt to equalize opportumity for all citizens regardless of racial or ethnic background to ackjeve an education.

This resarcher found no najor atudies which compared the responses 
to general knowledge and catesorization tacks of iower-socioecononic black, lower-socioeconomic thike, middie-sociocconomic black, and niddle-socioecononic white kindergarten-age children in an urbai sotting. A need existis to determine î a statistically simificant differenoe or patterning of responses is present within or between tbese four najor socioeconomic grouns. It appears that this type of information could be applied to develop education programs for beginning kindergarten chis rea.

For the purposes of this study, general knowledge and categorization are defined as follows:

1. General Knowledge: That information which may be acquired by an individual who experiences the "usual" opportunities in this society.

2. Categorization: The identification of likenesses between objects, substances, faces, or ideas (Glasser and Zimuerman, 1967).

\section{Statement of the Problem}

The present study was designed to determine if there are any "cultural" or economic level patterns of behavior in respending to tasks involving categorizing pictures and recalling general lnowledge. The Daberou School Readiness Device (1972), Which contains subtests for general knowledge and categorization, was used to esses: four groups of children: 1) iower-socioeconomic white, 2) lower-socioeconomic black, 3) middie-socioecononic white, and 4) niddle-socioeconemic black. The Daberon has not been formally tested utiljzing varying socioccononic groups, and it was felt that for comparative purposes this type of etudy would be valuble. Significant response patterns identified within economic or betwen cultural groms should be valubble to classroom 
teachers who art responstble for planning educational prograts for children from varying socioecsiomic statas (SES) levels.

The mill bypotheses tested in this investigation are:

1. No statistically significant difference exists between the total muber of general information and category concepts correctly identified by: a) lower-sociocconomic white, b) lower-zocioeconomic black, c) middle-socioeconowic white, and d) midlle-socioeconomic black subjects.

2. No statistically significant inter-grow response pattern differences exist in performing general hnowlesge and caterorization tasks on the Daberon.

3. No statistically simnificant relationshig exists between scores earned by all subjects on the Slosson Intelijgence Test $(1963)$ and those scores earned by all subjecis on the Diberon School Recaines: Device (1972). 


\section{CHAPIEL II}

\section{REVIEW OF THE LITTRATURE}

For the purpose of this study, a review of the literature relative to cognitive language development in children will center around four major areas: 1) Ianguage and cognition development in children; 2) cuitural differences in language and cognition development in children; 3) rescarch stuaies regarding language and cognition development utilizing varying SRS groups; and 4) educational impìications of cultural language differences.

\section{Language and Cognition Develogment}

Wheorists heve postulated rarious hypotheses to explain how children acquire language and cogaition.

Biber (196\%) stated there are important stages during wich i child organizes his anderstanding, his ideas, and the meaning of things and relationships in the world in which he lives, i.e., "objects becsme not only objects to do things with. but they also have names, uses, fwotions and cowe in different shapes and sizes." Tn other worde, objects can be claseifjed and grouped in various ways. Gne of the imnortant theories Bibe: conterids is that most children are able to function proficiently in regari to geneal knowiedge or classifjection, athough they may not progress thwongh these language developmental stages in the same manner. Srme atages of development, however, may be 
entirely missing, ard if this occurs, they need to be identified and appropriate treatment progrars established.

Osser (1970) discussed biological and social factors affecting language development. He stated that Lenncberg (196it) in his book New Directions in the Study of Ianguage proposed that ianguage developrent is a function of maturational factors and that human language is a species-specific phenomenon. The child's capacity to learn language is a consequence of maturation. Lenneberg reported there is no evidence that the onset of language is related to special training or that the capacity for language acquisition is related to special training. He further stated the capacity for language acquisition is intimately related to the maturation of aniquely human anatomical and physiological characteristics.

Chomsky (1965) maintained that a child's ability to produce and underistand novel sentences can be understood only by assuming he has an innate larguage capacity. Chomsky referred to a hypothetical set of innate mechanisms that permit the child to analyze incoming linguistic data and to produce messages. In other sords, linguistic principlos are not learned but rather are paxt of the child's innate conceptual capacitics; ard he acquires language by discovering jts morjying systefl or gramatical rules. The process characterized by the language acquisition device incorporates a bult-in set of specifications for correct gramurs, pius a testing capability which peraits the child to discover whicle particular grammar, out of a small set of correct grammars, is appropriate for the language to which lie is exposed. Whrough this system the child can anderstand novel sentences. It can be summized 
that Chomsky' $\mathrm{g}$ model of language acquisition providos only a passive role for environiental or social factors whereas the child is assigned a very active role in his own language development.

The environmentalists' pozition described by Mower (1960) can be summarized as followe: the infant begins to leare language by associating the sounds of the human voice, particalarly the mother's, with need-satisfying circumstances (e.g., milk drinking). Suhsequently, when he hears his own random babbling, he is more likely to repeat those sounds that are similar to the pleasurable sounds made by his mother. Mower felt that as the nother tends to roward the infant's sounds, he learns that his imications are generally reinforced, and thus he is on his way to learning those speech patterns. Mower torms this forn of language acquisition "imitation-reinforcenent."

Osser (1970) noted a relationship between the two opposing biclogical and environmental theories. He believed a point of convergence is present between the biological and environmentalizt theories, because they both agree that language is acquired in a social context and that there ne individual and group differences in linguistic perfornance. Hardy (1970) disagreed with Chonsky and felt because communicative skills must be learned, the environment in which learning takes place ajso plays an important role in detemaining the degree of skill ultimately achieved. Additionelly be beileved s elose relationship exists between commication skills and basic intellectual capacity. While a child lcarns to talk because of the nodel he hears, the basic intellectual endoment is of fundamental. importance in determining the dergee to which bis language will reflect the precision and the nuances of 
meaning, which are the finer points of language.

Children's grambar reflects, according to Brwin (1964), the norm of the commity in which they live. This language development theory was referred to as an "initative view." Erwin explained that children make errors and introduce ablueviations in an effort io approximate sentences hearỏ and develop more adalt-like langudge with the gradual elimination cf errors. Another view, which Emwin believed to be closer to the true Ianguage developmental process, was that development is described as the evolution of a series of linguistic systemis increasing in complexity and these changes in behavior reflect changes in the child's syntacticai rules. The base of generalizations and andogies, Erwin concluded, is formed by the child as he reflects the influence of listening to adults.

In their book School Readiness Iig and Ames (1972) presented a summary of the normal language and cognition sevelopment of five-yearcld children. Refer to Appendix A for this description.

\section{Cultural Differences in Language and Cognition Developuent}

Language charccterisijes of djsadvaniuged clibidren, and more especially black children, have been widely reviewed in the literatire. A predoninant characteristic of the najority of disadvantaged children (black and white) is that they lack the language facility nocessary for independent thinking and problea solving. Por these children, language deficieneies hamper the developnent of coneepts; theretore, specific training and language development are needed. In order that a child may receive special training to jmprove weak or wissing langrage con- 
cepts as soon after he enters school as possible, a process in the educational system to facilitate early identification of problem areas shovid be instibuted (Doyle, 1972).

Many characteristics of biack language have been ascribed to the doctrine of genetic inieriority of the Negro. Baratz (1969b) stated it was not whtil the 1954 Suprome Court decision concerning segregation in the pubic schools that the institutional tradition of regarding the Negro as genetically inferior was legally replacea by the idea that his behavior was pathological in the social sense, due to the history of slavery in this cowitry. Consequentiy, Baratz contends that the language difficulty experienced by the econonically deprived Negro child in an educational setting has been dise to an umerdevelopment of his language system that does not al. low language to function in aiding eognitive development.

Ralph (1967) explained that cultural differences in performarce on inteligence tests and in school achicvement imply a perceptuallanguage difference in regard to culturally disadvantaged chilidren. Further, he implied that these impairments are cumulative and the older the child becomes the greater the defjcit. He proclaimed that in their responses disadrantaged children illustrate a "poverty" of vocabulary and a "paucity" of words; thus, chijdren from lower-class familiez require about one year longer to reach "mature" articulations than their midale-class peers. The disadvantuged child's gramar and syntax were also identified as additional depressed areas of Leveioment. According to Bereiter and Engelmann (1966), children ibree to five years cld from lower-SES backgrounds are show to be retarded or 
below average in every inteliectual ability; consequently, they are functioning at least one year or more behind children of the same age frow higher-sts backgrounds. These authors described the verbal learning of the culturally deprived as the outstanding lacking characteristic and indicated that cognitive uses of language are severely restricted, especially in commication between adults and children in lower-SES homes.

Baratz (1969a) ảisagreed with Bereiter and Bngelman and found that when lower-SES and middle-SES black children were provided equivalent tasks, their ability to repeat a sentence accrateig largely depended on whether i.t was presented in the clisild's primary dialeet (black or Stardard Inglish). Consequently, she discovered that white midale-SES children were as handicappeó in repeating black dialect sentences as were black lower-SES childyen in repeating standard English sentences. In sumuary, within both groups the mistakes were systenatie intrusions between the primary dialect and the less familiar.

By virtue of class relationship or combon occupational function and social status, social groups tend to devalop strong communal bonds (Perustein, 1970). He stated:

If the working relationship of a gronp offers little variety, little exercise in decision naking; if successful assertion must be a collective rather than individual act; if the work task requires plysical manimiation rather than symbolic control; if the home is over-crowded and limits the variety of situations it can offer; if the chilaren socialize sach other in the environment, offering little intellectual stimulation; if all these attributes are found in one seiting, then it is plausible to assune that such a sociai setting could greverate a particular form of commication which would shape the inteliectual, social and affective orientation of the child. 
He presented two greneral types of linguistic codes (restricted and elaborate) which can be developed within a society. A resiricted code is more socially than conceptrally oriented, requires its users to share a range of implicit meanings, and appears limited and stereotyped in its expressive alteriatives. An elaborate code is conceprualiy oriented, does not rely heavily upor implicit meanings, and is poten... tially rich in the alteruatives for expression. Spealers limited to a restricted code may have difficulty swiching from this forn of commnication to other forms. Ie iound that in the middle-class population one tends to find people functioning within botil the elaborate and restricted code systems; yet within the lower-SEs or werking population a higher proportion of familiss seems to be limjted to a restricted code. Bernstein (1961) contends a child's langrage is maintained primarily through the process of developing linguistic reations before the child reaches the classrom and before the formal denands of the social structure are made upen him. Luria (1960) further stated that speech does not merely indicate correspondence in the environment but that it isolates, abstracts, and generalizes perceived signals and relates thew to certain categorias. Miss type of langugge orientation is guided and regliated by is speerh model that contiauously nakes avilable to the chila a linguistic sirueture that facilitates this slifi frow substance to response. Luria was referring to en elaborate linguistic code system which is generally establizhed within a widdle-SES population. The lcwer-SES family structure is lest formally organized in relation to the language and cognitive development of the child; and according to Bernstein (1961), this type of envixounest limite the prex- 
ception of the developing child. It appears that in tiwe the child learus to respond te, and makes responses to, stiudi that are immediately relevant and that the child's ability to deai with abstractions is adverseiy aifected.

Williams and Naremore (1909) agreed with Bernotejn's (1961) theory that social structures piace characteristic demands ypon their members for particular modes of language behavior. These modes of language regulate the cognitive and social development of children and thus serve to perpetuate the parent social structure. Their research examined the elaboration of responses by children from lower- and middle-.SFS levels. There vere three types of possible response modes: 1) simple: negative or affirmative; 2) naming; object, person, place, etc.; and j) elabcration: an explanation, description, or some type of story-telling. They found social-class differences were greatest in response olaboration when questions could be answered adequately by a simple "yes" or "no" or naming. Lower--SES chjldren tended more to supply the minimally acceptable response whereas the higher-SgS counterparts had a greater tendency to elaborate their remarks. For cxample, when asked to name their farorite TV show, the lowel-SES group supplied only the name of the show; the higher-SES group gave the rame and, in addition, went on to tell about the show, what happened, who was in the show, etc. When the questions required elaboration, however, the socioeconoinic differences all but disappeared. In other words, when the subjects were specifically asked io tell about or describe a particular incident or subject, all groups presented elaborate responses.

In addition, Williams and Naremore (1969h) noted that lower-Ses 
children tended to talk in the first person using a type of "seif.focused" mode of discourse or, in general, to empioy a particularistic and concrete style of speaking, Wher responding to a particular subject, they would consistently use remaxks such as "I like," "I saw," "I do," ete. By contrast higher-SES children tended wore to employ a variety of gramatical perspectives in their remarks and employed a greater use of third person, subject-noun phrases, reflecting a more general and ahstract perspective in their expressive language. For example, when asked how to play "hide and go seek," one subject replied:

Well, one person hides his eyes so that he can't see anything and all the other people go out and he counts to a certain, he counts so many, up to a hindred or so then he says, "Ready or not here I come," then he runs out and he looks for 'em. . .

Williams and Naremore concluded that the speech of the lower-SES children generally refiected a more context centered or "bound" style of speech as compared witli a more topic centered speech of their higherSES counterparts. This is consistent with Bernstein's (1961) thesis of social class differences and modes of specch.

According to Bailey (1968), children's system of language that is native to their environment is well eatablished between the fifth and seventh years of life. He noted that there are many speakers of nonStandard English whose basic patterns resemble those of Standard English, with pinarily an English vocabulary and similar phowelogy. One phonological difference recognized by Bailey was the terminal fading which resulted from relaxation of the musclez during articulation of the ends of rords so that the final syllable of a word was veakened or lost completely. There is a question, howeven, wethe this fading is 
due to the relaxation of arifolators or represents another gumatical syeten: such as creole. Thero is currenily no evidence to support, the theory the black language is a definite rom of the creole language, although they appear to be similar in many was.

According to Povich and Baratz (1967), language development of disadvantaged children does not represent a retardation of acquisition of language, but rather the children are leaming forms that do not appear in standard English. Their research indicated children use forms that are on the highest 1 evel of development according to Lee's Developmental Sentence Scale (1966). This secms to illustrate that disadvantaged children have a fully developed, but nonstanaard, language sysiem. Entwisle (1970) felt black children internaiize a different linguistic code as a consequence of the cultural forces impinging upon them. Ai the same time, because their subculture is an enclave with the white society, they are forced to internalize a second code, Standard English. If Baratz and Entwisle are correct, it appears to indicate that black children become proficient in both codes, and, therefore, are linguistically adranced as compared to white middle-class children.

J. M. B. Hardy (1970) asserted an opposing view in which he defined the disadvantaged child as a product of genes and environment and that both fantors are involved in his status and needs. The main theory he proposed was that regardiess of genetic batgrumd the disadvantaged child heis had tew advantages to enharce his social development and Iearning potential in school; thus, his abiaty to commicate during his eariy years suffer: severely. Further, according to Hardy the disadvantaged child may never develcp the momentum to overcone these carly 
coumunicatively negative experionces and, conseguently, it is most ibportant to obtain early identîi ication of problems and to follow up with educational programming.

\section{Correlation Between SES and Language Deve loument}

The following is a review of varicus research studies on language and cognition development conducted, utilizing varying socioecononic groups.

Jones and McMillan (1973) examined social cjass differences in speech produced by five-year-old children under three conditions ranging from highly structured to a more natural linguistic setting. Fesults indicated that generally middle-class children were more fluent and produced more granmatically complex sentences than lower-ciass children. The two groups produced equal numbers of communcation injis; howere:, the middle-class subjects produced significantly longer communication units. The two groups differed only slightiy in their use of pronouns except under the least structured conditions. The lower-class subjects produced significantly more pronouns urder this condition, which tends to support Bernstein's (1961) thoory regarding the restricted code of lower-class children conveying particularistic context-bound meanings. Using the Illinois Test of Psycholinguistic Abilities (ITPA) (1968), Stephenson and way (1972) examined the pycholinguistic abilities of black and white children between the ages of five and six from varying sociocconomic levels; and investigated the possibility of lower-SES children heing visual-motor oriented and micidle SES children auditoryvocal oriented. Results perealed that socioerononic status is signifi- 
cant]y related to psycholinguistic abilities. Tine ievel of performance and the pattern of psycholinguistic abilities of black children were relatively free from semantic influence of SES; however, the performance of white children appeared to be related to socineconomic status. The black and white lower-SES groups produced the most variability between the ITPA subtests, performing lower on the verbal tasks with the black children showing the lowest periormance. Performance on the verbal tasks was significantly below all other subtests for both groups of children. All groups showed a significant weakness on verbal expression tasks. Manual Expression subtest scores surpassed Verbai Expression scores at all levels. Further, Visuai Motor Association scores surpassed Auditory Vocal Association scores for black and white lower-SES groups. The performance of black lower-SES chiluren rovealed difficulties with the automatic language patterns measured on the ITPA. Performance on the Auditory Sequential Menory subtest was high for all black children with the level of performance unaffected by SFS. This study did not confirm the theory that the lower-SES levels are primarily visual-motor oriented and the midale-SES levels auditory-vocal oriented.

liolfram (1971) illistrated sorme similar and dissimilar features of southem white and black speech. He notid tie - 2 third person (he does, he goes, etc.) was not an imherent part of the black linguistic system; and its infrequeni occurrence can be attributed to "dialect importation," a larguage rontart phenomenon in whick non-indigenous forms are borrowed row another dialect wihout ics systematio incorporation in the target dialect. 
Stevenson et al. (1971) asked the question wather the correlations among various measures of leaming and perforwance differed according to the background of the children tested. They testad fourand five-year-old children from varying socjosconouic levels and foumd that generally the disadvantaged child iad nore difficulty than the advantaged child in understanding the questions and needed more prelininary instructions. Jeruchimowioz et al. (1971) investigated qualitative and quantitative differences in preschool children from varying socioeconomic levels. Results indicated there were significant differences in the receptive portion of the test between the proportion of errors on action words (verbs) and object or noun words made by the lower-SES children. Expressive verb errors were higher than noun errors for the lower-SES groups. Turner and Pickvance (1971) sampled 160 five-yearolds from differing SES levels on their ability to express uncertainty. Social class proved to be the more important factor in regard to those children who asked indirect questions, as significantly more middle-m class children asked indirect questions. It was concluded that the socialization procedures of the middle-ciass families were likely to encourage a child to parceive reality in terms of a range of possibie questions.

Two different studies were conducted by Gerber and Hertel (1969) and Howitd et al. (1970), using the ITPA to assess language abilities of four-, five-, and six-year-old children from differing sis levels. Their results indicated the eulturally disadvantaged had significantly lower language ages than their nondisadvantaged peers. Howard $\underline{\text { et al. }}$. felt the way symbols are perceived, as well as combined into meaningfui 
spontaneous discourse, depends upon experience and practice with langnage. In their study of four-year-olds from varying ses levels, Sitkei and Heyers (1969) found that the middle-class black and white groups, as compared to lower-class black and white children, excelied only in verbal comprehension and not in visual-motor iasks. It was thought that wite children rould excel over black children at the lower-SES levels and this showed to be significant only in visual discrimination tasks. Difference in race and class was limited to the functions that required the use of Standard Engish, and not in expressive language from their memory.

Entwisle (1968) conducted a study involving kindergarten, first-, third-, and fifth-grade children from lower- and middle-SES levels. Her sample included both black and white children. The subjects were presented ninety-six stimulus words representing several form classes (nouns, adjectives, verbs, and pronouns). Entwisle felt that free association to word stimulus was an efficient way of studying language development in young children because these associations are closely related to general linguistic competence and to verhai comprehension. Generally speaking, the results indicated the lsindcrgarten and firstgrade lower-class children were equal to or superior to the kindergarien and filst-grade middle-class children. The fifth-grade middle-class children, however, significantiy surpassed the fith-grade lower-class children. The results tend to suggest that as lorer-socioeconomic children progress through school, their linguistic abililies decrease. Hertzig et al. (1968) conducted a study involving Puerto Rican children and concluded that apparently atue to non-directed verbalizations 
in the home the children had greater trouble in school when taced with a system that made specific demands unon them. Tley found that although there was at least as much conversation and verbal exchange in the Puerto Rican homes as in the middle-class homes, the use of language appeared to differ in at least two respects: 1) middle-class fomilies gave instructions that were task directed and Puerto Rican verbalizatious tended to be social and affective; and 2) middle-class mothers tended to make sure task-directed instructions were understood and carried out while Puerto Rican mothers lad a tendency not to insist that instructions or directions were acted upon. In an educational setting, the Puerto Rican children more frequentiy used passive unresponsiveness as a form of nonverbal response than the middle-class children. According to Scholnick et al. (1968), socjal elass position affects discrimination learning, although it does noi affect concept, leaning. Further, they ncted lower-class children had less difficulty with complex tasks, which is contradicive to previously eited studies. Shriner and Mian: (1968) noted that in their study using nonsense words there was no difference between culturally advantaged and disadvantaged children in their ability to deal. With receptire nouns, expressive nours, verb forms, or possessivez-wa finding which also contradicts previously cited stadies. LaCivita et al. (1066) and beutsch (1965) found that as higher-SES children progress through school, they tend to become increasingly sophisticated in using gramatical cues to discery nord meanings. Deutsch conducted a four-year study of children fron various rasial and social clase groupings; and his research results, which agreed with Entwisie (1968), indicuted that black and white 
lower-class children are subject to a "cumulative defieit phenumenon" as compared with middle class children. This cumlative deficit takes place between the first- and fith-grade years. He believed there needs to be effective remedial and enrichment prograns which follow developmental stages, and that curriculun changes should be initiated early in a child's school experience.

Many variables are associated with setting and procedures in any type of language study, as noted by Dickie and Bager (1972), and need to be seriously considered by the reader. One very important variable is language fomiliarity since the language spoken in a classroom or testing situation may be quite different from what is spoken in the child's normal enviromment. It is, therefore, best to have an informal testing situation, thereby encouraging a more accurate language sample.

\section{Educational Implications}

The apparent lack of academic success within various cultural groups, especially lower-class blacks, whites, Chicanos, and Indians, is a major educational issue (Anastasiow, 1972). W. G. Hardy (1970) further noted that a high incidence of language, speech, and reading problems is knonn to exist among culturally disadvantaged chilriren. He attributed these significant problems to the child's environment sjnce it frequently fails to provide stimulation and language growth and ade-quate (by middle-class standards) models or patterns to develop acceptable and competitive speech habits. This is in agreement with J. M. B. Hardy (1970), who stated disadvantaged children suffer from a deprived enviuoment which does not allow for the active physical interaction 
necessary for a full development of a child's intellectual functioning. It was denonstrated by Baraiz and Shuy (1969) that black disadvantaged chilaren's language, while different in surface characteristics, contains the necessary linguistic structures to express abstract reasoning. Anastasiow (1970) related that when black disadvantaged cbildren are asked to repeat a sentence, they tend to alter it to conform to the regularities of their own diclect. This type of response suggests the disadvantaged child has a different, us opposeù to deviant language system, which agrees with Daratz and Shuy (1969). Anastasiow (1970) further suggested that all children are active processors of information; therefore, learning can only occur when children are allored to utilize the talents they possess in the manner that allows them to acquire more advanced skills and modes of thought.

The chances of the disadvantaged child becoming a fully functioning member in the mainstream of American societs, according to 0sborn. (1967), appear to depend upon his ability to succed in school. Further, he believed the "tive schedule" or curriculum progression of the public schools has been established by the progress of middle-class children and, consequerity, has presented a very serious problem for the disadvantaged child. Preschools and kindergartens designed specifically for the disodvantaged child can contribute greatly by providing the skills he will need to meet this established time schedule. Baughman and Dahlstrom (1968) saw the need to reduce the black-.white gap and asserted that educational programs should not he limited to black children, but rather should involve all groups. To neet this need there should be comprehensive school programs providing concrete 
incentive curriculums that instill in the child a desire to loarn. 0sborn (1967) strongly supported the need to find the most effective means of preparing disadvantaged ohildrea academically, as well as emotionally and socially, for the demands of the public achool system. Williams (1970) stated there is a strong correiation between economic opportunity and abjlity to function in the mainstream of society and he equated this with the ability to use the language of the society effectively. He felt that the artipoverty preschool progranis helped to ease disadvantaged children into a new social structure without the fear of losing their well established parental structure. Entwisle (1968) also was concerned with the need for equal educational opportinity and proposed that those who believed the schools would play a large role in overcoming the culture of poverty have great cause for concern. She felt the school failed to play this role, since if an individual failed to become sufficiently literate, all other parts of the educational process become adversely affected and the child either is rejected from or elects not to remain in the educational process. Basically, she viewed the problem as less and less success leading to less and less expectation of a child's success in school. It, therefore, becomes extremely important to identify areas of excellence or areas of relative achievement in disadvantaged children, for it seens gbvious that if a child is to imagine himself as succeding in an educational system, he will require successful experiences within the first two or three years of school (Entwis]e, 19\%0).

The classroon larguage problems of lewer-class children, as vicwed by Cazden (1970), have two possible explanations: 1) they have acquired less language than the midile-class child or 2) they have acquired a 
different language. The "different-language" thecry is strongly supported and has been expiained in the preceding revow of the literature by Williams and Narenove (1969b) and Baratz (1969b). Cazáen (1970) contends that within the educational framework therc needs to be more than a description of a child's grammatical compctence, and primary emphas is should focus on communicaticn competeac, i.e., "how the child perceives and categorizes sociaj and educational situations of his world. and differentiates his ways of speaking accordingly."

Bernstein (1970) agrecd with 0sborn (196i) that much of our school context is drawn from aspects of the symbolic woxld of the middle-slass, and when a disadvantaged child steps into school he very likely is stepping into a symbol system which has no link to his lifo outside the classroom. This link with his total environment lieeds to be present for a successfu] leaxning situation. Horton (1970) vieved success in school as the ability of a child to listen effectively, to receive, process, store, and retrieve information. He felt the needs of the culturally disadvantaged are really not the same as the middle-class child and this must be reflected in the educational systen. Horton further beicieved, as do many of the researchers cited, early intervention is extremely critical during the preschool and kinderrarien years, and focus should emphasize perceptual and language developmont. Minuchin and Biber (1968) suggested that success means developing emotional. strength along with specific skills. The teacher needs to accept relatively poorly articulated expressions without negutive evaluation initially which may produce a positive a imosphere for the child, thereby enhanelig his intellectual deveiopment. Sigel (:964) consequently 
stated, "Excessive demands for verbalizations may bring about a withdrawal or rebejlion from other aspects of learning." In view of this, educators must be sensitive to the needs of their students.

In sumary, Entwisle (1970) lighlighted the importance of spcech and language in our society.

If a child's speech anu language identifies him as a member of an outgrottp, when tagged as a member of that group he may be endowed with all the other nodal attributes of that group-relatively low econoiric status, low educational status, values that emptrasize immediate rather than delayed gratification, relatively

low power in the social heirarchy, or even having certain potential learnings below the inidde-ciass potentials.

It would appear that education is the inportant intervening factor between success or failure in our society, and unless there is early identification of educational needs, which many of the previousiy cited researchers have stressed, appropriate curriculua programs canrot be planned for the disadvantaged child. If this orcurs; it is very likely that the disadvantaged child will be unable to remain in the nainstream of our American society and be forced to exist with less than an equal opportunity. 
CHAPTER IIT

\section{METHODS AND PROCEDURES}

The present study involved thirty black and thirty white children with normal speech and language. All subjects were screetied to determine their rare, age, auditory acuity, speech inteljigibility, subject cooperation, and socioeconomic status (SES). Testing for intelligence was performed at the beginning of the testing situation.

\section{Subject:s}

Thirty white and thinty black children vith normel speech were selected from three portland public schools. Following the initial screening, f'ifteen lower-socjococnonic white, fifteen lower-scciocoononjo black, fifteen middle-socjoecononic white, and fifteer middle.socion. economic black children were selected for this study, using a random sampling table from at subject pool of 120. Participating in this study were fifteen female and fiteen male black subjecks and fourteen felaie and sixteen male white subjects.

\section{Variables}

Variablos controlled were age, race, alditory acuiby, speech indelligibility, subject cooperation, ard sosiseconomic statas. Sex was

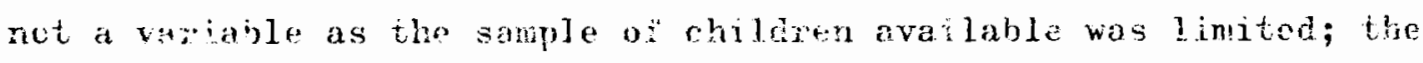
muber of chidren in each group possibly vould bave beor reduccd bad 
this variable been included.

Atre

The ages of the children tested ranged from 5-0 to 5-11 with a mean of 5-6. The age of each child was determined by subtracting his birthdate from the date he was tested,

$\underline{\text { Race }}$

Thirty black children and thirty white childrex were included in this study. To determine the race of black children for this study the criterion used was that estabished by Portiand Public Schooss: if a child had two black parente or one black parent and the other of a different race, the child is considered black.

\section{Auditory Acuity}

Each subject chosen to participate in this study receired an informal hearing screening which consisted of asking the subject, wo was placed across the room (approximately eight feet) with his back to the examiner, to repeat the following four sentences: "Put your hand up." "Tell me your naine." "Clap your hands." "Sit down in the chair." The exaniner used less intensity than a nornal sponking voice. Nomis hearing was further letermined by consulting with the classroom teacher andfor speecl clinician. Any child who was identified by the teacher to have a saspected hearing loss, difficulty following directions in class, or whose parents hal reported a hearing loss was not ineluded as i potential subject. 
Speeci Intelligibirity

Each subject was required to have 100 percent epeech inteiligi-. bjlity as determined by consuiting the classroom teacher, school records, speech clinjeian when available, and the judgment of this investigator.

Subject Cooreration

The ability of each child to remajn under stimulus control was determined by consulting with the classroom teacher and observation by this investigator. The subject's cooperative behevior was noted during adoinistration of the Slosson Intel]igence Test (1965), which was given prior to the selected items from the Daberon School Readiness Device (1972). Subjects vere required to remain under stimulus control for duration of the test in order to be considered potential subjests for this study.

Socioeronomic Status (SES)

The determination of socioeconomic status was made on the basis of the $\mathrm{E}, \mathrm{S}$. Burean of the Census Working Paper Number 15, Nethodology and Scoring gi sociorobonic status. Th: operating procedwe used in hiks etudy was to assigal a muber determined ky the occupation of the Gief incowe recipiend in the child's family, Iho numerical values rasging irom 01 to 40 were considered lower sociocononic status and those lrom 50 to 83, middle sociocenomic stetas. Aftex consultation with trit: schoo: principals, children on the fres lunch program also were considered lower sociveconomic siates.

Tha vccupation of the chef income recipient in the child's famir 
was obtained by fiest chocking school records on cach ehzld ruich listed the parents' occupation anc/or employers. If only the employer was 1 isted and not the occupation, the child andor a staff member familian with the parenis and occupation were constiled. Where both parent: nere cmployed, the orcupation used was that of the chief income recipient. If nejther parent was employed, the nunerical value of 0 ras assigued the subjoct.

\section{Intelligence}

The Slosson Iutelligence Test for Children and Adults (1963) was used to survey the intelligence of the subjocts. Children were not ex.cluded frou this study based on an intelligence rating; however, the intelligence rating was used for comparative purposes in data analysis.

\section{Instrumentation}

\section{Instruments}

The Daberon School Feadiness Device (1972) was designed as a soreening and teaching instrument. A high percentage of accurate re.sponses on the Dabergil judicates school readiness. This tool does not test a child to bis jumita; it is designed to be a simple neans of kre. dicting radiness for school activities, information gained trom this test may he used to identify future probien areas, the need for further diagnostic and prognostic study, information thai needs to be tallght in the chassrom, and needed medical and/or psycholorical evaluation. ine information abtained from this evaluation may be utilized to estublish a baseline for a continuing record of adicational pogress. 
The Daberon subtesis surveying General Knowledge and Categorization were administered to eaci subject. There were a total of thirty General Knowledge and six Categorization questions arimingtered to each subject. See Appendix B for a complete listing of the specific sublest questions.

The Slosson Intelligenoe lest (SIT) (1965) was designed as a short individual screening instrument and consists of a number of questions arranged in appropriate chronological order of difficulty t Tesing begins with the stimulus item one year below the subject's chronological age and is discontinued when a basal and ceiling have been established. The test yields a raw score, which can he converted into two types of derived scores: 1) Mental Ability and-2) Intelligence fuotient.

\section{Test Administration.}

During the first three wonths of the school year 1974-75, the Slosson Intelligence Test (STT) (1963) and portions of the Dabexon (1972) were administered to each subject. The examiner and child sat at a table in a well-lighted, quiet room. The STT was administored first to each child. Selected general knowledge and categorization items from the Daberon were then administered with the exaniner reading the test stimuli as they appeared in the test manual alud narking the appropriate boxes on the score sheet according to the following oode: I-correct; W-incorrect; N-no response; 1-inappropriate response. According to the testing nianual, an imapropriate response is one which is neither correct nor incorrect, is an echo of the question, or is not relevant io the subject. Echoing beharior, as deined by the manual, is repeating the inst word or phrase epolen by the exaniner. In order 
to obtain an accurnte asessment of a child's knowime, questions vere asked more than once if the examiner thought the child was confused o: inatentis. 'ane cotal adriaistration time for the two tests regurer approximately benty minutes.

\section{Data Analyeis}

Data were analyzcd in tems of means, standard deviations, t-tests, chi squares, Fisher's Exact Test, and andysis of variance, to determine if there wore any particular pattems ot intra- or intermoup responses on general bnowledge and categorization tasks.

Item analysis was accomplished by categorizing the responses as correst or incomect.

Chi square andyses were lised to determine whether any group missed iadividual test itens significandy more often than other groups.

Ihesponges to general knuwledge itens 12 to 30 were divided into general ond specific answers and chi square analysis ws used to deber. mine whether any group emitted significantiy more genesal or sperific concept-responses than other groups.

In ordar to determine a correlation between the zubjects' intaligence scures and their Daberon general knowledge and categorization scures a Pearson's Prodict-Yoment Correlation was alculated.

The level of simificance chosen for rejection or acceptance of the all bypothesis wa detemined at the o5 level of contidence, 
CHAPTER IV

BESLIITS AND DISCËSSION

\section{Resu1ts}

The present study sought to determine if there were any "cuitural" or econonic level patterns of behavior in responding to tasks inrolving categorizing pictures and recalling general knowledge. Subtests for general knowledge and categorization in the Daberon sehool Readiness Device (1972) were used to assess four major groups of children: 1) lower-socioeconomic (SES) white; 2) lower-socioeconomic (SFs) black; 3) middle-socioeconomic (SES) white; and 4) midale-socicecononic (SES) black children. There were a total of thirty general hnowledge and six categorization tasis on the respective Daberon subtests. Retar to Appendix B for a conplete description of these questions.

The null hypotheses tested were:

1. No statistically significant difference exists between the total number of concepts correctly identified by: a) lower-SES white, b) lower-SES black, c) middie-SES white, and d) middle-SES black subjects. Results of chi square analysis, and analysis of variance (Table I) sliowed lower- and middle-SES white subjects responded correctly liore often than lower- and middle-SES blach subjects on combined general knowledge and categorization tasks. This was significant at the .05 level; therefare, the null hypothesis was rejected. 
2. No statistically significant response pattem differences exist between SES groups in performing general knowierge tasks on the Daberon. Results of cini square analysis showed lower-and middle-SES white subjects expressed general knowledge tasks, utilizing general rather than specific concept responses more often than lower- and middle-SES black subjects. This was significant at the 05 level; therefore, the null hypothesis was rejectied.

\section{TABLE I}

ANALYSTS OF VARIANCE RESULTS FOR GENERAL KNOWLEDGE AND CATEGORIZATION TOTAL: SCORES $(\mathrm{N}=60)$

\begin{tabular}{lcrrr}
\hline Source of & df & $\begin{array}{l}\text { Sum of } \\
\text { Sariance }\end{array}$ & $\begin{array}{c}\text { Mean } \\
\text { Squares }\end{array}$ & F Ratio \\
\hline Race & 1 & 112.07 & 112.07 & $6.67^{*}$ \\
SES & 1 & .00 & .00 & .00 \\
Interaction & 1 & 1.07 & 1.07 & .06 \\
Within & 56 & 940.26 & 16.79 & \\
Total & 59 & 1053.40 & & \\
\hline
\end{tabular}

*Significant at the .05 level.

3. No statistically significant relationship exists between scores earned by all subjects on the Slosson Intelligence Test for Children and Adults (196j) and those scores earied by all subjects on the selected items from the Dibaron School Readiness Device (1972). Results of the Pearson's Product-ihomont Corrolation statistical test showed a moderately hirb correlation was evidenced witl a correlation coefficient 
of .573 . This was significant at the .01 level; therefore, the null hypothesis was rejected.

The Daberon subtests were administered to fifteen lower-SES white, fifteen lower-SES black, fifteen middle-SES white, and fifteen widdle-SES black children, ranging in age from five years to five years, elever months, with a mean age of five years, five months. Refer to Table IT. The subject's socioeconemic status (SRS) was determined on the basis of the U.S. Bureau of the Census Working Paper Nunber 15, Methodology and Scoring of Socioeconomic Status (1963).

TABLE II

MEAN AGE OF EACH SOCIOECONOMIC GROUP INCLUDED IN SPUDY

\begin{tabular}{lc}
\hline Socioeconomic Group & $\begin{array}{c}\text { Mean } \\
\text { Chronological } \\
\text { Age }\end{array}$ \\
\hline Lower-SES black & 5.6 \\
Lower-SES white & 5.4 \\
Midảle-SES black & 5.5 \\
Middle-SES white & 5.4 \\
\hline
\end{tabular}

General Knowledge

In order to determine if there vere significant differences between SES groups on total number of Ditberon general knowledge tasks correctly answered, the mean and standard deviation (S.D.) were calculated. Refer to T'able III for the total number of general knowledge tasks correctly identified within each SES group. The mean general knowledge 


\section{TABLE III}

GFNTRAL KNOWLEDGE SCORES* ACHIEVED BY THE FOUR MAJOR SOCIOECONOMIC GROUPS INCIUDDING MEAN AND S.D.

\begin{tabular}{|c|c|c|c|c|c|c|c|c|c|c|c|c|c|c|c|c|c|}
\hline \multirow[t]{2}{*}{ SES Group } & \multirow[b]{2}{*}{1} & \multirow[b]{2}{*}{2} & \multirow[b]{2}{*}{3} & \multirow[b]{2}{*}{4} & \multicolumn{2}{|c|}{ Subjects } & \multirow{2}{*}{$\begin{array}{c}\text { and } \\
7\end{array}$} & \multicolumn{4}{|c|}{ Correct Responses } & \multirow[b]{2}{*}{12} & \multirow[b]{2}{*}{13} & \multirow[b]{2}{*}{14} & \multirow[b]{2}{*}{15} & \multirow[t]{2}{*}{$\overline{\mathbf{x}}$} & \multirow[t]{2}{*}{$S . D$. } \\
\hline & & & & & 5 & 5 & & 8 & 9 & 10 & 11 & & & & & & \\
\hline Lower-SES white & 26 & 30 & 29 & 27 & 29 & 23 & 26 & 27 & 30 & 29 & 28 & 28 & 30 & 30 & 22 & 27.60 & 2.42 \\
\hline Lower-SES black & 29 & 27 & 28 & 21 & 29 & 30 & 27 & 14 & 26 & 27 & 15 & 21 & 25 & 27 & 24 & $2 ! .40$ & 4.74 \\
\hline Middle-SES black & 29 & 26 & 27 & 23 & 26 & 14 & 25 & 24 & 30 & 20 & 24 & 22 & 25 & 30 & 28 & 24.95 & $5.0 t_{t}$ \\
\hline
\end{tabular}

*Total score poesible: 30 . 
scores ranged from 27.86 for middle-SES white subjects to 24.40 for lower-SES black subjects. To determine if the differences in means were statistically signifjcant, t-tests were performed on the four SES groups. The values of the $\underline{t}$ appear in Table IV and indicate no statistical significance between lower-biack vs. midale-black SES groups, middle-white vs. lower-white SES grougs, and middle-black vs. Lwerwhite SES groups. Three groups, however, revealed a significant differ-

TABLE IV

VALUES OF $t$ RELATIVE TO GENERAL KNOWLEDGE SCORES FOR COMPARITSON WITII RACE AND SOCIOFCONOMIC STATUS

\begin{tabular}{|c|c|c|c|c|}
\hline Socioeoonomic Group & Mean & S.D. & $\underline{t}$ & $d f$ \\
\hline $\begin{array}{l}\text { Middle-SES whito } \\
\text { vs. } \\
\text { Lower-SES white }\end{array}$ & $\begin{array}{l}27.87 \\
26.60\end{array}$ & $\begin{array}{l}2.42 \\
2.42\end{array}$ & 0.31 & 28 \\
\hline $\begin{array}{l}\text { Lower-SES black } \\
\text { vs. } \\
\text { Middle-SES black }\end{array}$ & $\begin{array}{l}24.40 \\
24.93\end{array}$ & $\begin{array}{l}4.7 t_{1} \\
5.19\end{array}$ & 0.30 & 28 \\
\hline $\begin{array}{c}\text { Middle-SES black } \\
\text { vs. } \\
\text { Middle-SES white }\end{array}$ & $\begin{array}{l}24.93 \\
27.60\end{array}$ & $\begin{array}{l}5.19 \\
2.42\end{array}$ & 1.75 & 28 \\
\hline $\begin{array}{l}\text { Lower-SES black } \\
\text { vs. } \\
\text { Middle-SFS white }\end{array}$ & 27.87 & $\begin{array}{l}4.74 \\
2.1: 2\end{array}$ & $2.53^{*}$ & 28 \\
\hline $\begin{array}{l}\text { Middli-sES black } \\
\text { vs. } \\
\text { Lrwer-SES whjte }\end{array}$ & 24.93 & 5.19 & $2.0^{1 *}$ & 28 \\
\hline $\begin{array}{l}\text { Lower-SES black } \\
\text { vs. } \\
\text { Lower-SES while }\end{array}$ & $24 . t^{1} 0$ & $\begin{array}{l}4.7 / 4 \\
2.42\end{array}$ & $2.34 *$ & 28 \\
\hline
\end{tabular}

*Significant at the .05 levej. 
ence at the .05 lavel of signjficance on a two-tajled test: lowerblack vs. middle-white SES, t-value of 2.53 ; midole-black vs. middlewhite SES, t-vilue of $2.04 ;$ and lower-black vs. lower-white SES, tvalue of 2.34. These results indicate that lower-and middle-.SES white subjects answered correctly signjficantly more general knowledge tasks than lower- ard middle-SES blacir subjeets. Table $V$ summarizes the total number of correct responses by each SES group with an $N$ of 15 on the thirty general knowledge and six categorization subtest tasks of the Daberon.

Irdividual Subtest Items. An analysis of individual general knowledge tasks on the Daberor was conducted by using the chi square aralysis, and indicated a statistical significant aifference at the .05 level between ethnic and SES group responses. See Table V. The items identified incorrectly more often by black-SES subjects than white-SES subjects were $6,7,8$, and 26. In conparing lower- and middle-SFS black and white subjects, a significantiy greater proportion of lowerand middle-SES white subjects answered item 7 correctly. See Table VI. Although items 6,8 , and 26 did not show a statistical significant difference between ethric and SES groups ai the .05 jevel, they were significant at the .10 level of confidence. Refer to Table VI for a surnmary of the chi square analysis on itenis $6,7,8$, and 26 .

Patterns gi fesponse. The final area evaluated on general knowledge tasks was patterns of response for items 12 through 30 . Each item was extmined by using chi square andysis to determine any evident patterns of responses. The data collected on general knowledge concepts cvidenced a separation between general and specific arswers in regard 
TABIE V

NUMBER OF SUBJECTS IN ALL SES GROUPS RESPONDING CORRECTLY TO GENERAL WNOWLEDGE AND CATEGORI7ATION TASES ON THE DABERON

\begin{tabular}{|c|c|c|c|c|}
\hline Test Item & $\begin{array}{l}\text { Lower.white } \\
\text { SES }\end{array}$ & $\begin{array}{l}\text { Lower-Black } \\
\text { SES }\end{array}$ & $\begin{array}{l}\text { Middle-White } \\
\text { SES }\end{array}$ & $\begin{array}{c}\text { Middle-Biacl } \\
\text { SES }\end{array}$ \\
\hline \multicolumn{5}{|l|}{ G.K. Tasks } \\
\hline 1. & 15 & 15 & 15 & 15 \\
\hline 2 & 15 & 15 & 15 & 15 \\
\hline 3 & 14 & 14 & 14 & 15 \\
\hline 4 & 15 & 14 & 14 & 13 \\
\hline 5 & 14 & 11 & 14 & 12 \\
\hline 6 & 13 & 8 & 12 & 11 \\
\hline $7 *$ & 11 & 3 & 10 & 2 \\
\hline 8 & 10 & 5 & 9 & 4 \\
\hline 9 & 15 & 15 & 15 & 14 \\
\hline 10 & 15 & 14 & 14 & 11 \\
\hline 11 & 15 & 15 & 15 & 15 \\
\hline 12 & 15 & 13 & 14 & 15 \\
\hline 13 & 13 & 12 & 15 & 12 \\
\hline 14 & 15 & 15 & 15 & 13 \\
\hline 15 & 15 & 14 & 15 & 14 \\
\hline 16 & 14 & 14 & 14 & 15 \\
\hline 17 & 15 & 14 & $1 \varepsilon_{t}$ & 15 \\
\hline 18 & 15 & 15 & 15 & 15 \\
\hline 19 & 15 & 13 & 15 & 13 \\
\hline 20 & 15 & 15 & 15 & 15 \\
\hline 21 & 15 & 15 & 15 & 1.5 \\
\hline 22 & 15 & 15 & 15 & 1.5 \\
\hline 23 & 15 & 14 & 14 & 15 \\
\hline 24 & 13 & 14 & .15 & 14 \\
\hline 25 & 15 & 10 & 1.5 & 12 \\
\hline 26 & 8 & 8 & 12 & 7 \\
\hline 27 & 15 & 13 & 15 & 14 \\
\hline 28 & 11 & 11 & 11 & 8 \\
\hline 29 & 12 & 12 & 13 & 13 \\
\hline 30 & 9 & 10 & 10 & 11 \\
\hline \multicolumn{5}{|l|}{$\begin{array}{l}\text { Categoriza- } \\
\text { tion Tasles }\end{array}$} \\
\hline 1 & 15 & 14 & 15 & 15 \\
\hline 2 & 15 & 14 & 14 & 15 \\
\hline 3 & 15 & 14 & 14 & 15 \\
\hline 4 & 15 & 14 & 13 & 15 \\
\hline 5 & 14 & 14 & 15 & 14 \\
\hline 6 & 14 & 15 & 12 & 15 \\
\hline
\end{tabular}

*significant at the .05 level. 


\section{TABLE VI}

GENTRAL KNOWLEDGE QUESTIONS SHOWING A DIFFERENCE BETWEEN RACIAL AND SES GFOUPS TESTED

\begin{tabular}{|c|c|c|c|c|c|}
\hline Socioeconomic Group & $\begin{array}{l}\text { G.K. Ques- } \\
\text { tion Number }\end{array}$ & $\begin{array}{c}\text { Chi Square } \\
(1 \mathrm{df})\end{array}$ & Socioeconomic Group & $\begin{array}{l}\text { G.K. Ques- } \\
\text { tion Number }\end{array}$ & $\begin{array}{c}\text { Chi Square } \\
\text { (idi) }\end{array}$ \\
\hline $\begin{array}{l}\text { Lower-SES white } \\
\text { VS. } \\
\text { Lower-SES black }\end{array}$ & 6 & 2.40 & $\begin{array}{l}\text { Lower-SES } \\
\text { vs. } \\
\text { Middle-SES }\end{array}$ & 7 & .28 \\
\hline $\begin{array}{l}\text { Lower-SES white } \\
\text { VS. } \\
\text { Lower-SES block }\end{array}$ & 7 & $8.58 \% * *$ & $\begin{array}{l}\text { Lower-SES white } \\
\text { VS. } \\
\text { Lower-SES black }\end{array}$ & 8 & 3.32 \\
\hline $\begin{array}{c}\text { MiddlemsES white } \\
\text { vs. } \\
\text { Middle-ses black }\end{array}$ & 7 & $8.90 * *$ & $\begin{array}{c}\text { Middle-SES white } \\
\text { vs. } \\
\text { Middle-SES black }\end{array}$ & 8 & 3.40 \\
\hline $\begin{array}{l}\text { Middle-.SES white } \\
\text { vs. } \\
\text { Lower-SES black }\end{array}$ & 7 & $6.64 * *$ & $\begin{array}{c}\text { Middle-SES whjte } \\
\text { vs. } \\
\text { Midd le-.SkS black }\end{array}$ & 26 & 3.60 \\
\hline $\begin{array}{l}\text { Lower-sES white } \\
\text { vs. } \\
\text { Middie-SES black }\end{array}$ & 7 & $3.85^{*}$ & $\begin{array}{l}\text { Middle-SES white } \\
\text { vs. } \\
\text { Lower-SES biack }\end{array}$ & 26 & 2.40 \\
\hline Blaclis vs. whites & 7 & $17.36 * * *$ & & & \\
\hline
\end{tabular}

* Significant at the .05 level. * Significant at the .01 ieve 1. *** Significant at the o001 level. 
to the total concept. For a sumary of this inforintion refer to Table VII. General concept answers were considered to be conceptually oriented and expressed the overall meaning of the concepts presented in the general knowledge itens. Specific concept answers rejied heavily on explicit meanings and did not express the overall reaning of the concept. Refer to Appendix $\mathrm{C}$ for examples of general and specific responses.

An analysis of general and specific concept responses of the total population on all general knowledge questions reveaied lower- and middle-SES black subjects used speciilic responses significantly more often than lewer- and middle-SES white subjects. See Table VIII. In comparing lower- with nidale-SES black subjects and iower- with middleSES white subjects on their general and specific responses on general knowledge tasks, by using the chi square anaiysis and Fisher's Exact Test, it was found that four items tended to discriminate between the four SES groups: items 16, 18, 22, and 23. When lower-- and middle-SES black and lower- and middle-SES witite subjects were compared on item 16 , a significantly greater proportion of the white subjects answered this item with general concept responses. See Table IX. Results for item 18 (Tab:e $x$ ) indicate the middle-SES white subjects answered this item, using reneral concept responses, significantly wore often at the .05 level then middle-SES ilark subjects. The lower-SWS white subjects and lower-sES black subjects did nob show a significant difference on this itom and indicated a tendenoy to answer with approximately the same number of general and specific responses. When total black and white populations wore compared on itesi 22 , the white subjects omitted more 
TABLE VII

TOTAL NUMER OF CORRECT GENERAL VS. SPECIFIC CONOFPT RESPONSES

ON GENEIAL KNOWLEDCE TASKS BY ALL RACLAL AND SES GROUPS

\begin{tabular}{|c|c|c|c|c|c|c|c|c|}
\hline \multirow{2}{*}{$\begin{array}{l}\begin{array}{c}\text { G.K. } \\
\text { Question } \\
\text { Number }\end{array} \\
12\end{array}$} & \multicolumn{2}{|c|}{$\begin{array}{l}\text { Lower-SES } \\
\text { White } \\
\text { Gen./Spec. }\end{array}$} & \multicolumn{2}{|c|}{$\begin{array}{c}\text { Lower-SES } \\
\text { Blach } \\
\text { Gen./Spec. }\end{array}$} & \multicolumn{2}{|c|}{$\begin{array}{l}\text { Midale-SES } \\
\text { White } \\
\text { Gen./Spec. }\end{array}$} & \multicolumn{2}{|c|}{$\begin{array}{c}\text { Middle-SES } \\
\text { Black } \\
\text { Gen./Spec. }\end{array}$} \\
\hline & 13 & 4 & 12 & 4 & 14 & 1 & 15 & 3 \\
\hline 13 & 9 & 6 & 10 & 4 & 12 & 4 & 9 & 7 \\
\hline 14 & $1_{1}^{\prime}$ & 1 & 16 & 0 & 15 & 0 & 13 & 4 \\
\hline 15 & 13 & 4 & 10 & 17 & 14 & 2 & 9 & 7 \\
\hline 16 & 9 & 7 & 5 & 9 & 12 & 3 & 4 & 11 \\
\hline 17 & 14 & 3 & 12 & 3 & 13 & 4 & 13 & 5 \\
\hline 18 & 12 & 3 & 11 & 4 & 14 & i & 9 & 6 \\
\hline 19 & 9 & 6 & 4 & 9 & 13 & 2 & 8 & 5 \\
\hline 20 & 14 & 2 & 12 & 4 & 15 & 3 & 15 & 0 \\
\hline 21 & 15 & 0 & 1.3 & 2 & 15 & 1 & 13 & 3 \\
\hline 22 & 3 & 10 & 0 & 16 & 5 & 9 & 0 & 15 \\
\hline 23 & 9 & 7 & 8 & 7 & 12 & 2 & 6 & 10 \\
\hline 24 & 14 & 1 & 11 & 6 & 12 & 5 & 9 & 7 \\
\hline 25 & 15 & 0 & 12 & 3 & 15 & 0 & 11 & 2 \\
\hline 26 & 2 & 9 & 0 & 12 & 3 & 11 & 0 & 12 \\
\hline 27 & 15 & 0 & 14 & 4 & 15 & 0 & 14 & 1 \\
\hline 28 & 9 & 5 & 7 & 8 & 7 & 6 & 5 & 8 \\
\hline 29 & 8 & 6 & 11 & 5 & 7 & 10 & 8 & 6 \\
\hline 30 & 7 & 7 & 5 & 6 & 4 & 10 & 6 & 8 \\
\hline
\end{tabular}




\section{TABLE VIII}

RESULTS OF TOTAJ, POPUIATION ON ALL GFXEAA: KNOWLEDGE QUESTIONS WHCH REQUIHE GENERA, OR SPECIEIC CONCEPT PLSPONSES

\begin{tabular}{lccc}
\hline Socioecononic Group & $\begin{array}{c}\text { General } \\
\text { Response }\end{array}$ & $\begin{array}{c}\text { Specific } \\
\text { Response }\end{array}$ & Chi Square \\
\hline $\begin{array}{c}\text { Lower-SES biack } \\
\text { vs. }\end{array}$ & 173 & 113 & $7.67^{* * *}$ \\
$\begin{array}{c}\text { Lower-SES white } \\
\text { Middle-SES white } \\
\text { vs. }\end{array}$ & 203 & 81 & $17.4^{* * * * *}$ \\
$\begin{array}{c}\text { Middle-SES black } \\
\text { Lower-SES white } \\
\text { vs. }\end{array}$ & 167 & 120 & 1.533 \\
$\begin{array}{c}\text { Middle-SES white } \\
\text { Lower-SES biack } \\
\text { vs. }\end{array}$ & 203 & 81 & 74 \\
Middle-SES black & 173 & 123 & 0.165 \\
\hline
\end{tabular}

* Significant at the .01 level. ***Significant at the .001 level. 
F'ABLE IX

QUESTION 16. "MLAT DOES A DENTTST DO?"

GENERL AND SPECIITC CONCEPI

EXPRESEION

\begin{tabular}{|c|c|c|c|}
\hline Socioeconomic Group & General & Specific & $\begin{array}{l}\text { Chi Square } \\
\left(1 \mathrm{~d} f^{j}\right)\end{array}$ \\
\hline Middle-SES black & 4 & 11 & \\
\hline Middle-SES white & 12 & 3 & $8.53^{* *}$ \\
\hline Lower-SES black & 5 & 9 & \\
\hline Middle-SFS white & 12 & 3 & $6.15 * *$ \\
\hline $\begin{array}{l}\text { Middle-SES black } \\
\text { vs. } \\
\text { Lower-SES white }\end{array}$ & 4 & $\begin{array}{r}11 \\
7\end{array}$ & $3.86 *$ \\
\hline $\begin{array}{l}\text { Lower-SES black } \\
\text { vs. } \\
\text { Lower-SES white }\end{array}$ & 5 & 7 & 0.92 \\
\hline $\begin{array}{l}\text { Middle-SES white } \\
\text { vs. } \\
\text { Lower-SES white }\end{array}$ & 12 & 3 & 2.40 \\
\hline $\begin{array}{l}\text { Lower-SES black } \\
\text { vs, } \\
\text { Middle-SES black }\end{array}$ & 5 & 11 & .28 \\
\hline
\end{tabular}

*Significant at the .05 level. **Significant at the .01 level. 
TABLE $\mathrm{X}$

QUESTION 18, "WHAT' DO YOU DO WHAN YOU ARE HUNGRY?" GENERAI ANT SFECIFIC CONCEPT' EXPLESSION

\begin{tabular}{|c|c|c|c|c|}
\hline Socioeconomic Group & General & Specific & $\begin{array}{l}\text { Fisher's } \\
\text { Exact }\end{array}$ & $\begin{array}{l}\text { Chi Square } \\
\text { (1df) }\end{array}$ \\
\hline Middle-sES black & 9 & 6 & & \\
\hline vs. & & & $0.040 *$ & \\
\hline Middle-SES white & 14 & 1 & & \\
\hline Lower-SES black & 11 & 4 & & \\
\hline vs. & & & 0.165 & \\
\hline Middle-SES white & 14 & 1 & & \\
\hline Middle-SES black & 9 & 6 & & \\
\hline vs & & & & 1.4 \\
\hline Lower-SES white & 12 & 3 & & \\
\hline Lower-SES black & 11 & 4 & & \\
\hline $\begin{array}{c}\text { vs. } \\
\text { Lower-SES white }\end{array}$ & 12 & 3 & & .19 \\
\hline Lower-SES black & 11. & 4 & & \\
\hline $\begin{array}{c}\text { vs. } \\
\text { Middle-SES black }\end{array}$ & 9 & 6 & & 0.65 \\
\hline Lower-SES white & 12 & 3 & & \\
\hline Middle-SES white & 14 & 1. & 0.299 & \\
\hline
\end{tabular}

*Significant at the 0.05 level. 
general concept responses than the black subjects and this was significant at the .05 level. These results are provided on Table XI. The

TABLE XI

QUESTTON 22, "WHUT IS A KEY FOR?"

GFNEHAL ANT SPECITIC CONCEPT

EXPIESSION

\begin{tabular}{lccc}
\hline Socioeconomic Group General & Specilic & $\begin{array}{c}\text { Fisher's } \\
\text { Exact }\end{array}$ \\
\hline $\begin{array}{c}\text { Total black population } \\
\text { rs. }\end{array}$ & 0 & 31 & $0.12^{*}$ \\
Total white population & 8 & 19 & \\
\hline
\end{tabular}

*Significant at the .05 level.

results for item 23 shown on Table XII revealed middle-SES white subjects used general concept answers more often than middle-SES black subjects. This was at the .01 level of significance. Results further indicated the middle-SES white subjects responded wiih relatively more general concept answers than lower-SES white and black subjects. This was sirnificant at the .10 level and the null hypothesis was rejected; however, this does reveal a tendency toward the .05 level of significance.

Categorization

Refer to Table IV for the complete listing of categorization tasks correctly identified by each subject. To determine if there were significant differences between SES groups on total mimber of Daberon categorization tasks correctly anshered, the mean and standard deviation 
TABLEE XII

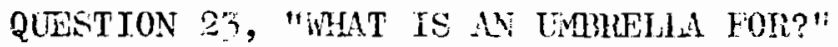

GENERAL AND SPLC IFIC CONCEPT

EXPRESSION

\begin{tabular}{|c|c|c|c|}
\hline Sorioeconomic Group & General & Specific & Chi Square \\
\hline $\begin{array}{l}\text { Middle-SES black } \\
\text { vs. }\end{array}$ & 6 & 10 & $723 * *$ \\
\hline Middle-SES white & 12 & 2 & \\
\hline $\begin{array}{c}\text { Middle-SES white } \\
\text { vs. }\end{array}$ & 12 & 2 & 3.09 \\
\hline Lower-SES white & 9 & 7 & \\
\hline $\begin{array}{c}\text { Lower-SES black } \\
\text { vs. }\end{array}$ & 8 & 7 & 000 \\
\hline Lower-SES white & 9 & 7 & 8.07 \\
\hline $\begin{array}{c}\text { Lower-SFS black } \\
\text { vs. }\end{array}$ & 8 & 7 & 0.79 \\
\hline Middle-SES black & 6 & 10 & \\
\hline Lower-SES black & 8 & 7 & \\
\hline $\begin{array}{r}\text { vs. } \\
\text { MiddJ.e-SES white }\end{array}$ & 12 & 2 & 3.55 \\
\hline $\begin{array}{c}\text { Middle-SES black } \\
\text { vs. }\end{array}$ & 6 & 10 & 1.85 \\
\hline Lower-SES white & 9 & 7 & \\
\hline
\end{tabular}

**Significant at the .01 level.

(S.D.) were calculated. See Table XIII. The mean categorization scores ranged from 5.95 (middle-SES black) to 5.40 (middle-SES white). In determining if there were significant differences in scores between SES groups, t-tests were applied. No significant difference was noted between socioeconomic status or racial grouns at the .05 level of significance on a two-tailed test. Refer to Table xIV. The only group which approximated the .05 level of significance were middle-SES white vs. 
TABLF XI II

MEANS AND STANDARD DEVTATTONS FOR AK

HACLAJ AND SOCIOECONONIC GROUPS

ON CATEGORIZATJON* TASKS

\begin{tabular}{lll}
\hline & $\overline{\mathrm{x}}$ & $\mathrm{S.D}$. \\
\hline Socioeconcmic Group & & \\
\hline & 5.87 & 0.05 \\
Lower-SES white & 5.55 & 1.20 \\
Middle-SES white & 5.40 & 1.41 \\
Middle-SES black & 5.93 & 2.49 \\
\hline
\end{tabular}

*Total score possible: 6 .

TABIE XIV

VALUES OF $t$ RELATIVE TO CATEGORIZATION SCORES

FOR THE' COMPARISON OF RACE AND

SOCIOECONOMIC STATUS

\begin{tabular}{|c|c|c|c|c|}
\hline Socioeconomic Group & $\overline{\mathbf{x}}$ & S.D. & $\underline{t}$ & df \\
\hline $\begin{array}{l}\text { Middle-SES white } \\
\text { vS. } \\
\text { Lower-SES white }\end{array}$ & $\begin{array}{l}5.40 \\
5.87\end{array}$ & $\begin{array}{l}1.41 \\
0.05\end{array}$ & 1.46 & 10 \\
\hline $\begin{array}{l}\text { Middle-SES black } \\
\text { vs. } \\
\text { Lower-SES black }\end{array}$ & $\begin{array}{l}5.93 \\
5.53\end{array}$ & $\begin{array}{l}2.49 \\
1.20\end{array}$ & 1.27 & 10 \\
\hline $\begin{array}{l}\text { Middle-SES white } \\
\text { vs. } \\
\text { Middle-SES black }\end{array}$ & $\begin{array}{l}5.40 \\
5.93\end{array}$ & $\begin{array}{l}1.41 \\
2.49\end{array}$ & 1.76 & 10 \\
\hline $\begin{array}{l}\text { Lower-SFS white } \\
\text { vs. } \\
\text { Lower-SES black }\end{array}$ & $\begin{array}{l}5.87 \\
5.63\end{array}$ & $\begin{array}{l}0.05 \\
1.20\end{array}$ & 0.34 & 10 \\
\hline
\end{tabular}

*Significant al the .05 level. 
middle-SES black groups. The zesultis show a t-value of 1.76, which is significant at the .10 level, and indirate midde-Ses black subjects tended to answe more categorization tasks correctly than middle-SES white subjectss.

\section{Intelligence Correlation}

To determine the relationship between the children's intelligonce quotients (IQ) as measured by the Slosson Intelligence Test for Children and Adults and the Daberon general knowledge and categorization subtest scores, a Pearson's Product-Moment Correlationi was calculated. The results indicated a moderately high correlation between the scores with a correlation coefficient of .573 and a z-value of 4.40, which is significant at the .01 level.

\section{Discussion}

The primary purpose of the study was to determine if there were any "cultural" or economic level patterns of behavior between four major groups of kindergarten-age children in responding to tasks involving categorizing pictures and recalling general knowledge, using subtests frum the Jaberon School Readiness Device. This study tested three null hypotheses, which will be discussed in this subsection.

The first hypothesis tested and subsequently rejected in this investigation was that no statistically significant difference exists between the total number of general knowledge concepts correctly identified by: a) the lower-SES white, b) the lower-SES black, c) the niddleSES wite; and d) middle-SES hlack subjects. Results indicated that wher interaction of race is considered, a statistical significant dif- 
ference exists on general mowledge concepte correctly identified on the Daberon. As shown on Taible IV, white subjects correctly identifjed more concepts than black subjectio, and socioeconomic status level did not appear a ractor in the difference noked. No significant difference was noted, however, when the same lower- and middle-SES ethnic groups were compared. See Table IV.

Social-ciass differences ir regard to speech and language expression have been an area of concern, and over the past ten years much research has resuited. Cazden (1970) reporied from his study on school. language problems of lower-class black and white children that socialclass differences were not significant enough to correlate with the language problems seen in the classroom. It appeared ethnic a ifferences were a more significant factor in separating the two groups. Many studies examining social-class differences in speech and language expression, however, found the middle-class children exceeding the lowerclass on a variety of tasks (Jones and McMillan, 1973; Jeruchimowics, 1971; Gerber and Herte1, 1969; Hertzig et al., 1968; and Scholnick et al.: 1968). For a review of these studies refer to chapter II. In studies which included race and socioeconomic status as independent variables, results indicated that race and SES vere significant factors in separating the groups, with the middle-sws white and black subjects perforwing significantly better than lower-SES white and black subjects (Deutsch, 1965; Entwisle, 1968; and Sitkei and Meyer's, 1959). The results of this study of kindergarten-age children from the Portland area in their expression of general knowledge concepts do not appear to agree with previously stated research. In this study regarding correct or 
incorrect responses to general krowledge coneepts, race was the significant factor and not. SES, with the white population verforuing significantly better than the black population. A possible explanation for the results is suggested by previously mentioned research in Chapter II. It appears that language typically spoken in the home of culturally disadvantaged childsen, especially lower and middle-SES black children, has a tendency to be poor in context and verbal expression of thought (Gerber and Hertel, 1969). It has been stated by Howard et al. (1970) that children from lower-status families frequently Jack the exvironmental opportunities provided by higher-status families from which valuable academic foundations begin to form. Many questions chosen for the Daberon, according to the manual, were based on the Gesell developmental norms for normal children. Appendix A summarizes the normal developmental skills of a five-year-old (Ilg and Ames, 1972). Results of this study indicate that the white subjects in the Portland area have had more experiezces in relating to genera] knowledge concepts and, consequent $1 y$, are better able to correctly respond to these concepts.

Individual general knowledge tesi item scores for each ethnic and SES level. were compered for possible statistical significance. As slown on Tolble VI, four items angeared to separate cultural groups: item 6, "put your finger on the last one"; iten 7 , "Put your finger on the second one"; item 8. "Put your finger on the next to the last one"; and iten 26, "hat is a cont mate out or?" Figure $1^{-}$illustrates how many snijects in each othnic and SES group answered these items correctly. Three of tive fonr icads ircorrecty identified nore often by blacks thare whites dealt with spatiol relations (itens 6,7 , and 8 ). 
The subjects were required to indicate, by pointirg, which child in a picture of five children in a row approaching a dooway, correctly represented the spatial concept boing asked. Itom 7 evidenred the strongest significant difference betweer ethnic broups, showing lowerand middie-SEs white subjects perforning significantly better than lower- moi mjddle-SES black subjects. No significant difference was

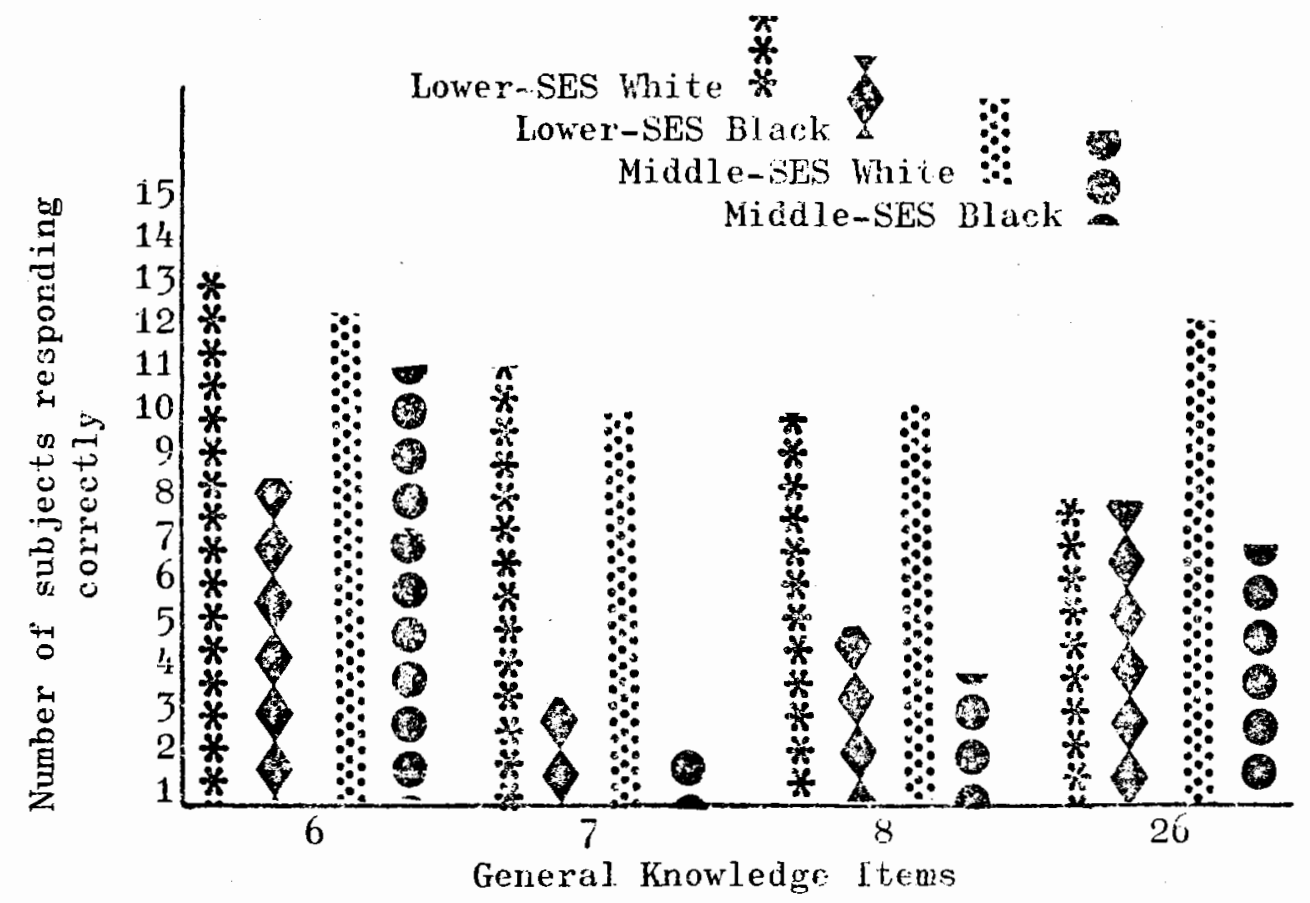

Tjgure 1. General knowledge items slowing a difference between ethic group; correctly responding to these items.

noted when lowex-SES subjects were compared to middle-SES subjects, Signilicant differences were noted only when blacks were compared to whites, with the white subjects perfurming significanty better. It appears that kindergarten-age white children can understand and relate to spatial relationships significantly more correctly than black kindergarten-age children. Responses between ethnic and SES groups to itens 6, 8, and 26 did not show a statistical significance; however, responses 
evideneed a sirong tendency toward approaching the .05 level of significance, with wite subjects responding more correctly than black subjects, as shorm in Figure 1. These results suggest that spatially related concepts such as first, last, second, and next to the last, possibly are expressed more often or specifically taught in white homes than in black homes.

All subjects appeared to have difficulty answering items 28,29 , and 30 , in which they were asked to tell how a spocn and a shoe, a bird and a dog, and wood and glass are different. See Table V. The Daberon manual states that these are six-year-old items and require the subject to usc a rather high level of abstraction to ansiver correctly. White subjects performed slightly better than black subjects on these items. The results tend to support Bernstein's (1961) theory, previously stated in Chapter II, regarding elaborate and restricted linguistic code systems. His research concluded culturally advantaged children tend to function within an elaborate code system and are able to verbalize abstractions significantly beiter than culturaliy disadvantaged children, who interact within a restricted code system.

The secoud hypothesis tested and subsequently rejected was that the four ethic and SES groups reveal no statistically significant difference in response patterns to general knowledge and categorization tasks on the Daberon. The response to iterns 12 through 30 could be scored correct or jncorrect and be further divided into a general or specific answer within the general concept. Bernstein's (1961) theory on restricted and elaborate code systems was used as a guide in classifying general and specific answers. The general arswers were consid. 
ered conceptually oriented, expressed the overall meaning of the concept, and did not utilize explicit meanjug within the total concept. The specific concept answers represented more of a restricted code or linguistic system, were mare sociaily than conceptually oriented, and relied heavily on expicit neanings and not the overall meaning of the concept. For example, a general conceptual response to question 23 , "What is an umbrella for?"i would refer to the person's cverall protection from the rain, and specific conceptuai responses would refer to protection of certain parts of the body, i.e., head, hair, and clothes, from the rain.

This analysis of patterns of responses does not evaluate answers as right or wrong but only if the items were answered with a general or specific expression of the concept. Questions cocild, therefore, be answered with a specific conceptual response and silil be considered correct; also, questions could be answered with both a specific and general conceptual response.

An analysis of the total general and specific concept expression resulis (Table $\mathrm{X}$ ) rerealed a statistically significant difference between ethnic gionps, but not SES level. White subjects answered significanily more itens with a general concept-type response than black subjectis.

A statistical analysis of individual general knowledge tasks (12 through 30 ) was conducted to determine if any items significantly separated ethnic or SES levels in regard to how they were ansivered. Results revealed four items $(16,18,22$, and 25$)$ showed a significant difference between general ox specific couceptual expression. Figure 2 illustratos 


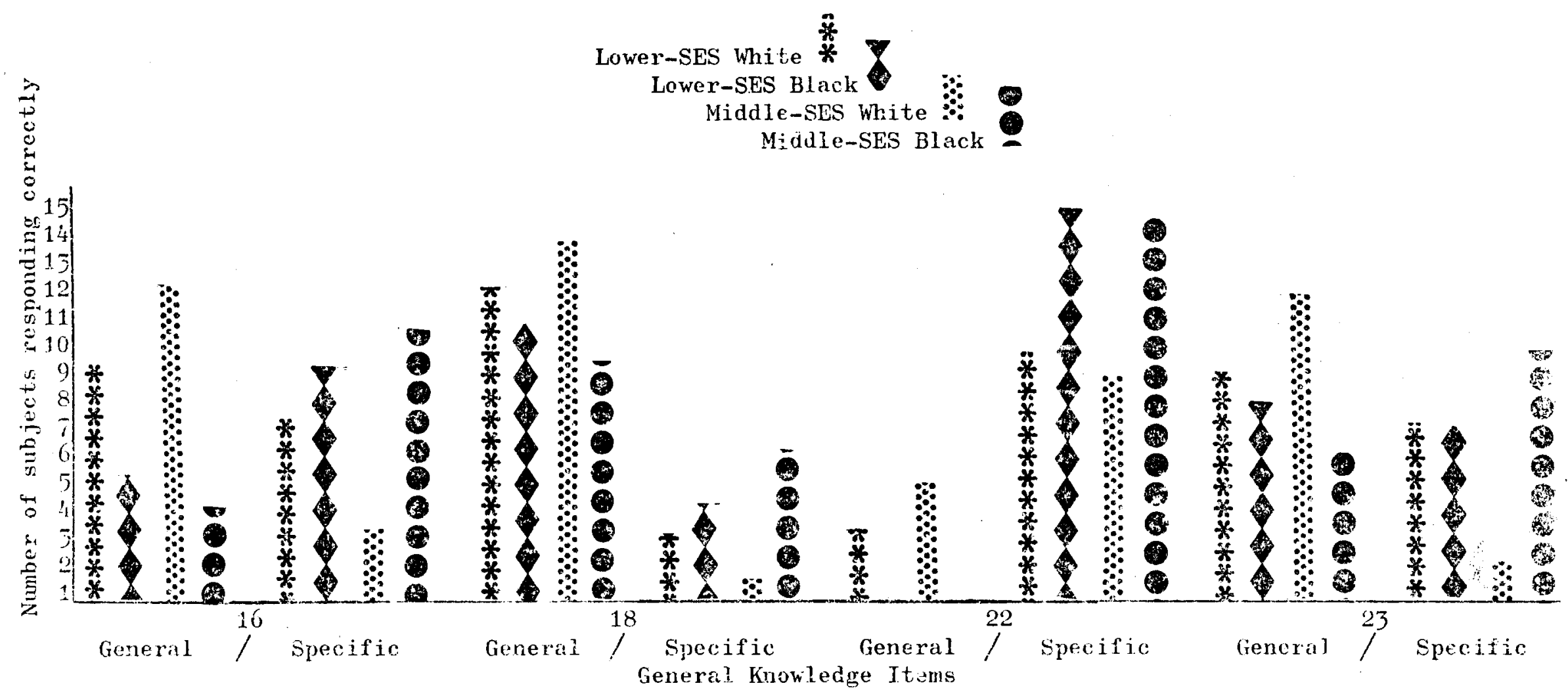

Figure 2. General kiowledge itelis showing a statistical significance between ethric groups on generai and specific types of responses. 
how many subjects in each ethnic and SES group answered these items correctly. Responses to iten 16, "What does a dentist do?" revealed the greatest statistically significant difference between cuitural or ethnic groups, with middle-SES white subjects enitting significantly more general concept answers than middie-SES black subjects. Generally speaking, on this item white subjects resporded with significantly rore general concept-type responses than black subjects. These results further appear to indicate a significant difference in performance between ethnic groups but not between SES level. Responses to item 18, "What do you do when you are hungry?" revealed no significant difference between lower-SES white and lower-SES black subjects. Middle-SES white subjects, however, answered this item with significantly more general concept answers than middle-SES black subjects. This itern showed a tendency to significantly separate middle-cjass cthnic groups. In answering item 22, "What is a key for?" all groups tended to answer with specific concept responses; however, white subjects were shown to emit significantiy more general concept responses than biack stojects. Finally, stetistical significant difference between groups was found in answers to item 23, "What is an umbrella for?" Middle-SES white subjects emitted nore general concept responses than middle-SES black subjects. A sumnary of all general knowledge questions and how they were answered (Table VlIT), reveals white subjects, especially middle-SES white subjects, enitted significantly more general conceptual responses than black subjects. Bernstein (1961) noted that by virtue of ciass relationship or as a resul. of common occupational function and social class, social groups tend to develop strong communal bonds. He further classified these 
commual bonds into twe grenerai types of lingristic code systens (restricted and eiaborate) which can be developed within a society. Bernstein belioved a chjld's langhage is naintajed primarjly through the process of developing linguistic relations before the elild reaches the classroom. These linguistis code petterns, previousiy outlined in Chapter II, can be seen in the black and white subjects in this study. Generally speaking, white subjects apneared to function within an elaborate code system which does not rely on implicjt meanings and utilizes higher level. abstract thinking, whereas black subjects appeared to function with the restricted code system, relying heavily on implicit meaning. For example, in item 22, "What is a key for?" black subjects responded in reference to locking or unlocking specific iteus, such as a door or a garage, as compared to a significant number of white subjects responding with the general concept of the key sorving to lock or wlock without reference to a specific item involved with the key. These results also tend to support hilliams and Naremore (1969) study in wich they found middle-SHS white children atiljze more elaborate responses when asked to describe or talk about certain topics than lower-SES white subjects. The present study, unlike that of Williams and Naremore, utilized both black and white children from lower- and unjdde-SES leveis. Tho significant difference noted in use of general vs. specific concepts resulted in an ethric rather than SES difference. It wuld appear the white children in this study have been exposed more to an claboxate-type code linguistic system in the houe and are, therefore, better able to express thoughts verbally utjlizing this type of linguistic code. The black subjects represented in this study, hovever, 
responred significantly more ofien utjlizing a restricted code systen which could be considered reflceive of the type of lingujstic code system evolving from their howe.

Categorization responses revealed no siguificant difference between ethnic or SES lovel. Figure 3 illustrates how many subjects in each ethnic and SES group responded correctly to categorization tasks cr. the Daberon. Althongh categorization responses did not require genera? or specific answers, items 4, 5 , and 6 , which required the subjects to name the category represented by the picture, showed a difference in how many responses it took the subject to respond correctly. If the subjects did not answer the first time or started naming individual pictures under the general concept, the examiner was permitted to ask again which general category the pictures represerited. In revieving the number of times each subject was asked to name a category, it was noted that seven of the fifteen middle-SES black subjects were asked again to name the category "food" and correctly responded, whereas only two of the fitteen midale-class white, two of the fifteen lower-class black, ard one of the fifteen lower-class white subjects were aslied twice what category the pictures represented and correctly respondea. Generally speaking, the subjects who were asked a second tine tended to name the individual pictures on the first response as opposed to naining the general concept. White subjects named the general concept on the first response to the categorization question more frequently than did black subjects. This evidence appears to further support Bernstein's (1961) restricted and eilaborate code theory and also further supports the results of suiject's responses to general knowledge asing general or specific answers. The 


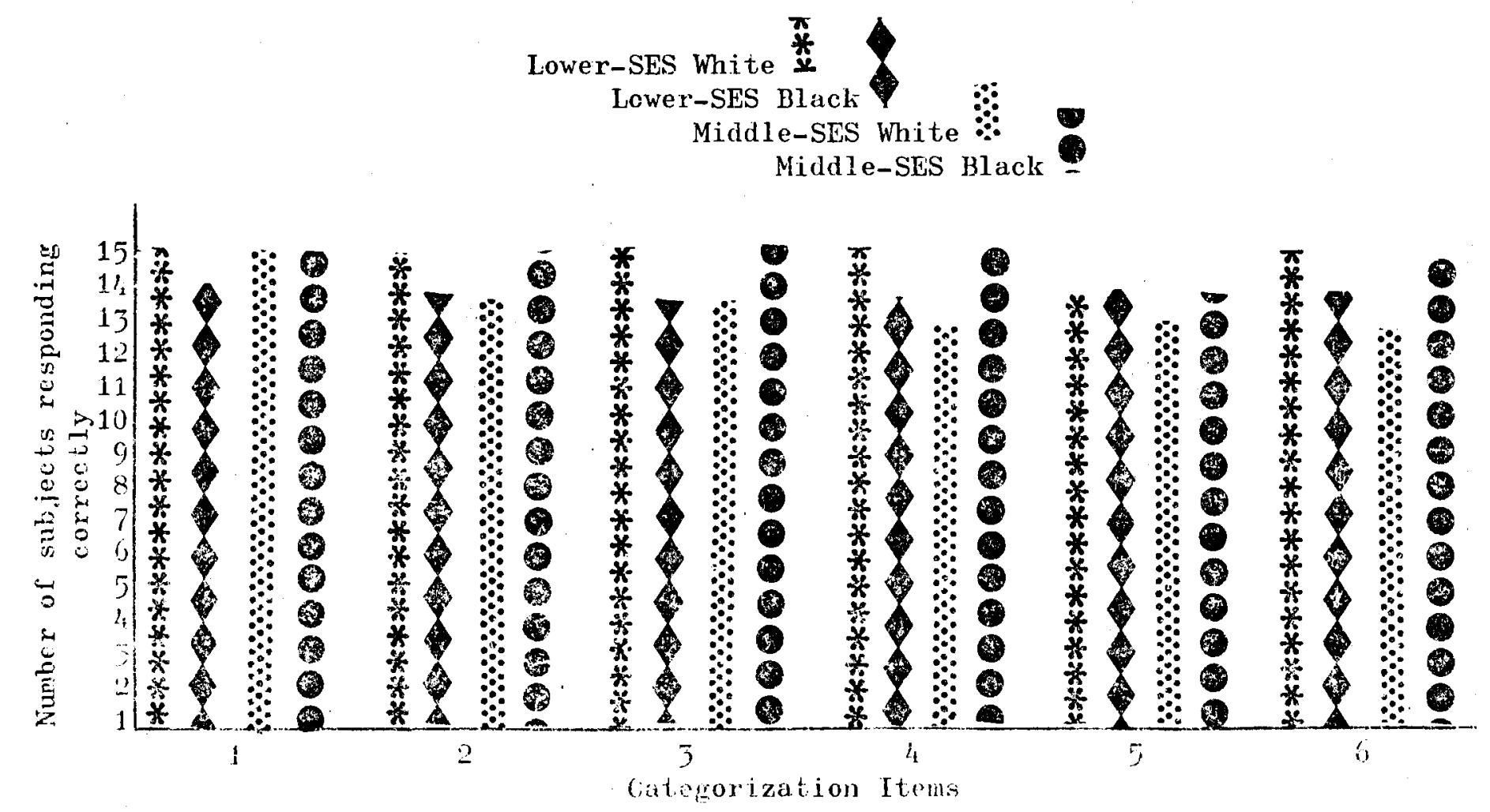

Pigure 3. All categorization items on the Daberon School Reariness Device. 
categorization questions involved three basic concept areas: food, clotling, and animals. This examiner foels that these concepts are very basic and poss bly every child, black or white, cones in contact and becomes fami: with each one. This possibly could explain why there was no sjgnj: "ai difference between ethnic or racial groups.

The this: hypothesjs tezted and rejected in this investigation was that no statisticaily significant relationship exists between scores earned by all subjects on the Slosson Intelligence Test for Children and

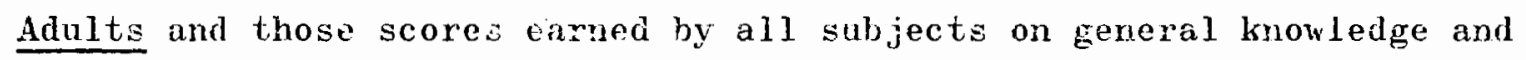
categorization subtests of the Daberon. Results of the Pearson's Product-loment Correlation indicate the degree of relationship was statistically significant, revealing a moderatcly strong relationship between the Daberon subtest scores and the Slosson scores. The results appear to suggest that a child's ability to function in the areas of general knowledge and categorization correlate positively with the ir general intelligence. General intelligence is, therefore, reflected in the range of an individual's information and his ability to discriminate with and between categories. 


\section{CHAPTER V}

\section{SUNMARY AND IMPLICATION}

\section{Summary}

This study sought to determine if there are any "cuitural" or economic level patterns of behavior in responding to tasks involving categorizing pictures and recalling general knowledge. The Daberon School Readiness Device (1972), which contains subtests for general knowledge and categorization, was used to assess four groups of children: 1) lower-SES white, 2) lower-SES black, 3) midile-SES white, and 4) mildle-SES black. The study involved thiriy olack and thirty white children between the ages of five years and five years, eleven ronths. All subjects were screened to determine race, age, aulitory acuity, speech intelligibility, subject cooperation, and socioeconomic status (SES). Testing for intelligence was performed at the beginning of the testing situation.

The stuly was designed to determine whether one ethnic or SES level group would correctly icientify significantly more general knowladge and/or categrorization atems on the Daberon then other ethnic and SES groups. Further, the study sought to deterwine i: there were any significant patterns evident between ethnic and SWS groups in the way they xesponded to general knowledge tasks. Finally, the study was conducted to determine whether there was any statistically significant relationship between seores carned by all subjects on the Stosson Intelli- 
gence Test for Children ard Adults (1965) and those scores earned by all subjects on the Inberon School hoariress Derice (1972).

Results of the study indicate white subjects answered sjgnificantly more geñeral knowledge tasks than black subjects. Significant djeferences also were noted in pattems of responses to general kuowlengo tasks. White subjects responded significantly more often with gencal concept-type responses as opposed to specific concept responses than black subjects. No statistical significance wa noted between ethnic and SES groups in responding to categorization tasks. Finally, statistical signifinance was present between Slossen Intoligence Test scores and those scores earned on the general knowledge and categorization subtests of the Daberon School Readiness Derice. These results indicate a positjre correlation between a child's ability to function in the area of goneral lnowledge and categorization and his general intelligence.

It is postulated that factors which might influence Daberon general knowicige subtest scores and pattems of responses are: 1) the inilaence of Linguistic systems within the chiid's hone environment and 2) the subject's ability to respond by utilizing aistract thinking rather than by relying heavily on inplicit reaning.

\section{Implications for Clinic and Future Rescarch}

\section{Clinie}

The results of this study appear to indicate to classroom teachexs andior speech elinicians that the Daberon could be utilizel to levise language enrichment programs in an educational setting. Ain important part of this enrictment prograni should be based on providing a wore 
elaborate linguistic code system tor disadvantared children, especiajly blach children. Bernstein (1961) stated that n the white middle-class population, we tends to find people functioning within woth the elaborate and restricted code systems. This stury revealed a signjficant proportion of the white population ntilized an elaborate code system in respouding to general lnowledge concepts, while the black population cupoered to function within the restricted rode system. Thjs investigaior suggests that people who can function within both an elaborate aud restricted code system will experience more mobility in the jinguistic world. These people, therefore, will not be restricted to exist within a confined enviroment which limits their nobility rithin the social structure of the society.

Findings of this investigation also may inply that memory span is an important alement in utilizing genera! knowledge acquired in the sehool seting. If the child canot process and recall from wemory general information tanght in the classroom, his success in school might be very limjted. Much of today's educational programing depends upon the chid's ability to recall general knowledge. It, therefore, appears that early identification of menory span competenes is a necessary area of liagrostic evaluations or screening programs.

Researcli:

This investigator suggests that further researed utilizing the Daberon al:o might include a test for nenory span. Dîforent schoolaged ses and ethic groups conld be used. Results oi the research might indicate a relatjurship ketween providing geueral exporiences in the classom an the child's ability to vilize these experiences. 
Also, it is suggested that a nore extensive linguistic analys is be done on assessing the types or patterns of responses derived from generai knowledge questions. The Laura Lee Developmental Sentence Scoring instrunent cond be utilized to accomplish a more in-depth investigation of general and specific concept responses. Such analysis would provide extensive information relative to the child's linguistic competence and ability to function within the total society.

Another analysis which might be performed could assess a more extensive categorization test. This investigator believes that the Dareron subtest for categorization is too limited in the scope of items provided to give a representative evaluation of the subject's categorization abilities. A further analysis of categorization abilities utilizing school-aged subjects from varying ethnic and SES levels might provide data showing a significant difference between the groups investigaled.

Finally, it is felt that a different intelligence test should be wilized in further research assessing kindergarten-age children. The Slosson Intelligenco Tesi appesred to be an inadequate instrument for this age group, since the intelligence quotient scoves were slightiy elevated for all etbnic and SLS groups eviluated. 
SEIECTED BIDLTOGRAPIY

ANASPASIOW, Nicholas J., Educating the culturaily different child. Viewpoints, $48(2), 21-'$ t $^{2}$ (1972).

BAILET, B. L., Some aspects of the impact of linguistics on Ianguapre teaching in disadvantaged commities. Flementary Fugisb, 15 , $570-579(1968)$.

BANGS, T., Largnage Ieaming Disorders of the Pre-Acalemic Child. New York: Appleton-Century-Crofts (1968).

RAJATz, $f .$, Language in the enonomiealiy disadvantaged child: A perspective, Asha, $10(4), 143-145(1968)$.

BimAZ, J., A bidialectual task for determining langnage proficiencies in economically disadvantaged Negro children. Child Development, $40(3), 889(1969 a)$.

RARATZ, T.: Iangruage and comnitive assessment of Negro children: Assumptions and research reeds. Asha, 11(3), 87-91 (1969b).

BADATZ, J., and SHUY, R., Tearling Black Children to Read. Washingtor, D.C.: Center for Applied Lingistics (1969).

BAUGHLN, E. E., and DAHLSTROM, W. G., Negro and White Children: A Psychological Study in the Thral Soutb. New Yorls: Acadente Fiess $(1968)$.

BRREJTh, C., and ENGEIMAN, S., Teaching Disadvantaged Children in the Preschool. Engelwood Cliffs, N.j.: Prentice-Hall (1966).

BERNSIITN, B. Social class and linguistic developmert: A theory ai social learning. In A, H. Halsey, J. Floud, and C. A. Andoran (Nds.). Education, Eccuomy and Socicty. New York: Free Press (1961).

BERNSTER, B., A sueiolilguistic aproech to socialization with some reference to educatability. In F. Williams (Ed.), Language :mH Poverty. Chicago: Markhan! Publishing Company (1970).

BIBrR, B., Educational needs of young deprived children. Childhood Education, 4 it, $30-36(1967)$. 
BROTMAN, M. A. (Ed.), Larghare remediation for the disadvantaged preschool child. Monopraphs of The Society for Research in Cinild Development: $33(8)(1908)$.

CAZDEN, C. B., The neglected situation in child language research and education. In F. Willians (Ed.), Langugue and Poverty. Chicago: Markham Publishing Company (1970).

CHomsKY, N. An, Aspects of the Theory of Sintax. Cambridge: MIT Press $(1965)$.

DANZER, V., GERBER, M. F., and LYONS, T. M., DABERON A Screening Device for School Readiness. 9regon: DABERON Research (1972).

UELTSCH, M., The role of social class in language development ard cognition. American J. of othopsvchiatry, 35(1),78-88 (1965).

DEUTSCH, 1!, aid BROWN, B., Socinl influence in Negro-white intelligence differences. J. of Social Issues, 20, 24-35 (1964).

DICKIE, J., and BAGUR, J, S., Consigerations for the study of longuage in young low-incone minority group children. Merrill-Palmer Quarterly, $18(1), 25-58(1.972)$.

DOYTE, M., Language acquisition of children...nommal and disadvartaged. Contcoporary Education. 43, 161-164 (1972).

ENTWLSL, D., bevelopinental sociolinguistirs: Tmer-city children. Anterican J. of Sociology, $74,37-49$ (1968)

ENTWISLE, D., Semantic sysiems of children: Some ascessments of social class and ethnic differences. In F. Williaus (Ed.), Language and Poverty. Chicago: Markham Publishing Company (1970).

ERWIN, S. M., Intation and structural change in children's language. In E. H. Lomeber (Ed.), New Directicns in the Study of Language: Cambriage: MIT Press $(196 \overline{4})$.

GFIRBAR, S. F., and HFTTEI, C. G., Language deficjency of disadvantaged children. I. Speech Hearing Res., Vol. 12(2), June (1969).

GLASSER, A. J., and ZIMUHALY, T. L., Clinical Interpretation of the Wechsier Invel ligence scale for Children (Misc). New York: Grome and stration $(1967)$.

GOLDEN, M., and BCRNS, B., Social class and cogitive development in infancy. Merrill-palmer Quarcerly, 14, 139-150 (1968).

IMLSEY, A. H., FLOLD, J., and NOERSON, C. A. (Eds.), Economy, Eduoation ami Sociedy. New York: Free Press (1961). 
HARDY, J. M, B., Some biologie and social aspects af commentative problems, In W. G. Hardy, Commatication and the Disadvantaged Child, Baltimore: The Williams and wilkins Conpany (1970).

MABDY, W. G., Commication and the Disadvaitaged ChiId. Baltimore: The Williams and Wilkins Company (1970).

HWRTZI, M. E., BMCH, H. G., THOMAS, A., and NENDEZ, 0. A., Class and ethic differences in the responsiveness of preschool children to comitive demands. Monographe of the Society for the Research in Child Davelopinent, $3 \overline{3}(1968)$.

HOLLAND, A., Comment on language deficiency of disadvantaged children. J. Speech Hearing Rles., 13, 440-441 (1970).

HOPPER, R., and NREMORE, R. C., A Practical Introduction to Communication Development. New York: Harper \& Kow Publishing Company $(1973)$.

HORTON, K. B., Eariy language programing tor preschool culturally disadvaniaged children in day cure sertings: Evaluation and impact. In H. G. Hardy, Commenication and the Disadvantaged Child. Baltimore: The Williams and Wilkins Colipiay (1970).

HOWARD, M., HoOPS, R., and HoKJNNON, A. J., Ianguege abilities of children with difiering socioeconomic Uackgrounds. Jo of Learning Disabilities, $3,328-335(1970)$.

$\geqslant$ ILG, F., and AMES, L., School Readiness. New York: Harper \& Row Publisling Compuny (1972).

TEUCHIMOHEC, R., CASTELLO, J., and BACUS, J. S., Knowl edge of action and object words: A comparison of lower-midile-ciass Negro preschoolers. Child Development, 42(2), 455-464 (1971).

JGISSON, K. R., Teachers' attitudes toward nonstandard and Negro dialect. Educational Digest, 36, 45-8 (1971).

JONES, P. A, , and MoMILLAN, W. B., Speech characteristics as a function of social class and situational factors. Chjld Development, i4 4 (1), 117-121 (1973).

HTRK, S. A., Eand McCARTHY, J. J, Mllinois Test of Paycholinguistic Abilities. Chicago: University of Jllinois Press (1968).

LaCIVITA, A. M., KEAN, T. M., and YMMOTO, K., Sociveconomic status of children and acquisition oi granmar. J. of Edueaion Roseareh, $60,71-7^{4}(1966)$. 
I LE, L., Deveiopental senterce types, a method for comparing normal and deviant syntactic development. J. Speech Hearing Dis., 31 , $311-378(1966)$

LENNENBERG, E. H., New Directions in the Study of Iniguage. Cambridge: Mif Press $(1064)$.

LURIA, A. R., The Role of Speech in the Formation of Mental Processes. iondon: Pergainon Press (1960).

MudRTHY, D., Development in children. In L. Camichael (Ed.), Nambal of Child P'sclioiogy. New York: Wiley and Company (1951).

MINUCHT, p., and BTHER, B., A child developmental approach to languape in the preschool disadvantaged child. In M. $\Lambda$. Bottman (Ed.), Language remediation for the disadvantaged preschool child, Moncoraph of the Society for Research in Child Development, 33 (1968).

MOWER, 0. H., Learning Theory and the Symbolic Process. New York: Wiley and Conpany (1960).

OSBORN, J., Teacher and teaching language to disadvantaged children. In S. Minuchin, V. Montalvo, G. Guerney, B. Rosrian, and F. Schumer, Finilies of the Slums. New York: Basic Books (1967).

OSSER, H. Biological and Social Factors in language development. In P. Williams (Ede), Language and Poverty Chjcago: Markham Puìlishirig Compary $(19 \overline{70})$.

POVICH, E., and BARATZ, J., Language sophistication of eccromically disadvantaged children. Unpublished nanuscript, 1968.

RALH, J., Language and speech in culturally disadvantaged child: Inplications for the specch clinician. J. Speech Hcaring Dis., 32 , $203-214(1967)$.

SCHOLNCK, E. K., OSLER, S., and KATZFNELLENBOGFN, H., Diserinination ieaming and concept identification in disudvartaged and middleclass children. Child Development, 39, 15-26 (1968).

SHRiNER, T., Economicilly deprived and aspects of language skills. In 1. Trovis (Ed.), Handbogk of Speech Pathology and Mulologr. Tew Ycrk: Appieion-Century-Crofts (1971).

SHnNER, T. H., and MINTR, L., Morphological structires in the language of disalvantaged ani advantaged children. J. Speech Hearing Res., $11,605-610(1968)$ 
SIGEL, I. E., and OLMSTFi, P., Modification of Claselficatory Coupetence and Level of Representation Among Lower-Citse Fogro Kindergarten Chijdres. Detroit: récrill-Palmer mstilato (robi).

SITKEI, (i. F., and MEYERS, E. C., Comparative structure of jntellect in middle- and lower-class t-year-olds of two cthic troups. Developmental Psychojoovs: 4, 592-604 (1969).

SLOSSON, R. I., Slosion Irtallicence Test for Children and Adults. Fast Aurora, New York: slosson Educatiunal Publicutions (1963),

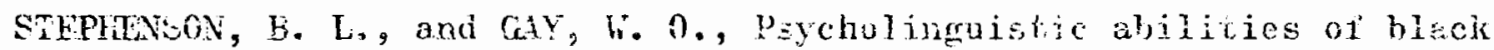
ard white children frum iour SES levels. Excuptional Children, $38(9), 705-709(1972)$.

STEVENSON, H. W., WILLTAM, A. M., and COIFMAN, D., Interrelatione alone leaming and performane tasks in disadvantaged childrel. ${ }^{3} .0 \pm$ Educational Psycholngy, 62, 179.187 (1971).

TERPEL, G. K., and WTESIEY, M., Social class and the nature of the incentives in discrimination learning. I. of Alunomal and Sonial Psychology, 59, 270-272 (1959).

TCREER, G. J., and PICKVANCE, fi. E., Social class differences in the expression of uncertainty in five-year-old children. Lanyung:and Spefeh, 14(4), 303-325(1971).

J.S. Bureau of the Cersus working Faper Number 15, liethodologer and sog. ing of Socioeconomic Status. Washington, D.C, (1965).

WeLCHR, D. W., Communication and academic achievement in inner-cit: children. In w. G. Hardy, Comumicalion and the Disalyantage: Child. Baltimore: The Willians and Wilkins Company (1970).

WhLIMS, F., Language, attitude and social change. In F. Willians (bu.), language and Poventy. Chicago: Markham Publishing Conpany $(1970)$.

WhLLMN, F., and NAREMOQE, R. C., Social class differeuces in chiliren's: syntactic performares A quantitative analysis of fieid study data. J. Speech Hearing Res., 19(4), 777-793 (i969a).

WILLAMS, F., and NAFENORE, R. C., Franctional antalys is of social class differences in modes of speech. Speech Moingraping, 36, 77-100 $(1969 \mathrm{~b})$.

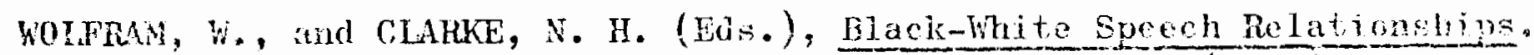
Wostingrou, D.C.: Conter for Applied Linguidics (1971).

ZIMMERMN, T. L., STETER, V. G., aud EVAT, R. L., Erescigon Language Mamual. Cojumbus, Oino: Charles E. Merrilt Prublishing Company $(1969)$. 
APPENDIX $A$

GESELL DEVELOPMFNTM PATTERNS FOR FIVE-YEAL-GID CHILREN

\section{Five-Year-01ds}

The child is typically striving to be good. The child's health is generally very good. Most five-year-olds like to be close to their parents, like to be in the kitchen with mother talking with her, helping and working with her. The mother recognizes the child's desire to please and enjoys having her child around her.

Perhaps no place can better provide five-year-old's needed expansion than kindergarten. The child wants to be told vhat to do. Fives do best in a morning session of school. The child is ready to do group activities and the new inteilectual challenges that school provides. He knows his letters, in part at least, and he can count to twenty; he is alert to new words and repeatedly asks their meaning; he listens well and wants to carry out instructions.

Pive may appear shy when approached by an examiner in his class.room and asked to come and play games with her. He is ready for adventure. The exaniner reaches a hand out to the child and he usually responds in kind and this makes lim feel more secure as he walks down the corridor with the examinex. Most five-year-olds will give their are with case, a lew gesture the number with fingers, and some may need to count their fingers to arrive at their age. Thirty to forty percent of the children know the month of thejr birthday; the majority simply say, 
"I don't know," when asked what month they were boin in. The child can usually tell you how old his brother or sister is and their names; however, one question at a time. He often thinks of his family size in terms of including himseli in the total figure.

The five-year-old is able to inlibit his approach to the paper and pencil which await him on the table. Ile is able to answer questions without being distracted by the paper and pencil. The child will pick up his pencil directly with his dominant hand, not picking it up first with the non-dominant hand and then transferring it to the dominant hand. His grasp is usually an easy three-finger grasp near the tip of the pencjl. He often confuses letters and numbers, and understands "print" better than "write." A typical five-year-old can print his first name but only a smaj.l percentage can print the whole last name. He may or way not know the names of the letters he prints and he prefers to print capital letters. He will often reverse some of his letters. In copying forms, he often names the form before he will draw it. Often he will tell you how he feels about the forvi: "easy," "simple," or "kinda hard." The conquest of a circle, cross, and square has been relatively mastered within the past two years even though the quality of response has changed with age. Ho has little difficulty naming cominon body parts, and carrying out single or dontile commands.

Five-and-a-half-year-0 $1 \mathrm{ds}$

The cooperative five-year-oid is changing into a demanding, oppos-ing child. He tends to combat force with force and hy doing so only adds fuel to the fire. The child is gajning a new ability to stand up 
for hiuself. A child of lilis age is inss likely to show the extrenes of his personality at school. Ile is berinuing to expeess himself more freely. His shyuess has left him and generally he is quite willing to drop what he is doing and go with an cxaminer. His body now noves with a looseness, having lost the stiffer erectness charactiostic of five. He slips into the chair at the examing table quite naturally and is ready and eager to do whatever he is asked. He definitely knows his age. He is beginning to grasp the ifea of a birthdate, especially the month in which his birthday occurs. He can tell you abcut his brothers and sisters, and accurately reports their ages and names. Ie can tell you more about his father's occupation than "work," such as build, prints, makes something, etc.

The writing posture is much the same as when he was five, with a good hold on the pencil and the free hand flat on the table. A high percentage of five-and-a-half-year-olds can print their name and over 50 percent can print their last name or first initial of their last name. Typicaliy you can still see sone reversals ard some substitutions but not as often as when the child was five. The five-and-a-half-yearold has an easier time of copying forms; he can breeze through a circle, square, triangle, cross, and plis. He is beginning to write numbers but you will see many reversals in order and rigures. He has the ability to express enotion--te1l how a picture of a child lonks--sad or happy. iie can nawe common body parts and animals. Games the five-and-a-hall-yearold likes are raried; they like to plny with objects and prefer gross motior activities outacrs. 
APPENDIX B

DAPERON GENERAL KNOWLEDGE AND CATEGORIZATION QUESTIONS

General Knowledge

1. What is your first name?

2. What is your: last name?

3. How old are you? Fingers used

4. Tot your finger on the one in the middle. (Examiner shows picture.)

5. Put your finger on the first one. (Examiner shows picture.)

6. Put your finger on the last one. (Examiner shows picture.)

7. Put your finger on the second onc. (Examiner shows picture.)

8. Put your finger on the next to the last one. (Examiner shows picture.)

9. Which is bigger, a tree or a flower?

10. Which is slower, a car: or a bicycle?

11. Which is heavier, a stove or a sock?

12. Where do we buy gas?

13. Where would you find a cor?

14. Whon do you go to when you are sick?

15. What does a firemar do?

16. What does a dentjst do?

17. What do you do when you are sleepy?

18. What do you do when you are hungry?

19. What do you do when you are thirsty? 
20. What are books for?

21. What is a stove for?

22. What is a key for?

23. What is an umbrella for?

24. What are houses for?

25. What is a chair marle of?

26. What is a coat made of?

27. What is a house made of?

28. How are a spoon and a shoe different?

29. How are a bird and a dog different?

30. How are wood and glass different?

\section{Categorization}

Match to appropriate category

1. Food.

2. Clothing.

3. Animals.

Verbally desinnate what general category pictures illustrate

4. Foor.

5. Cluthing.

б. Animals. 
APPENDIX C

EXAMPIES OF GENERAL AND SPECTFIC RESPONSES TO

GENERAL KNOWLEDGE ITEMS $16,18,22$, AND 25

General Concept Responses

Item 16: "What does a dentist do?"

1. Fix your teeth.

2. Examines your teeth.

3. Fxamines and cleans your teeth.

4. He fixes your teeth.

5. Checks teeth and makes sure you don't have cavities.
Specific concept Responses
1. Take oui some of the teeth if they are rotten.

2. Puil vour teetin.

3. Take out your teeth.

4. Puli out teeth and wash teeth and give you a toy.

5. Take off one of your teetli and put gold in it.

Item 18: "What do you do when you are hungry?"

1. Go eat.

2. Eat.

3. Get something to eat.

4. You eat.

5. I eat something.
1. If we have some cookies, I get them.

2. You just ro to the store or iix lunch, dinner, or snack.

3. Hake a peanut butter sandwich.

4. Teji Darlay to buy îrench fried or hambuigex or something.

5. Get up and fix breakfast.

Item 22: "What is a key fur?"

1. Locking.

2. Unlocking.

3. Starting a vehicle.

4. Locking and unlocking.

5. Locking, wilocking, and starling.
1. For you open your door, or open youx back trunk.

2. Unlock a door.

3. Open the garage or back dook.

4. If you want to lock the door or unlock the door.

5. To open somebody door. 
Item 23: "What is an uubrella for?"

1. For rain so can't get you soaked. 1. Keep rain off head.

2. To keep the rain off you when 2. So rain won't get on you with it's raining.

3. When it raining so won't get

4. Rainy days so you won't get

your new school clothes.

3. For the rain not get on your soaking wet.

5. To protect from rain.

4. If hair pressed-get umbrella so hair won't get wet.

5. To cover your head so your head won't get water on it when raining. 